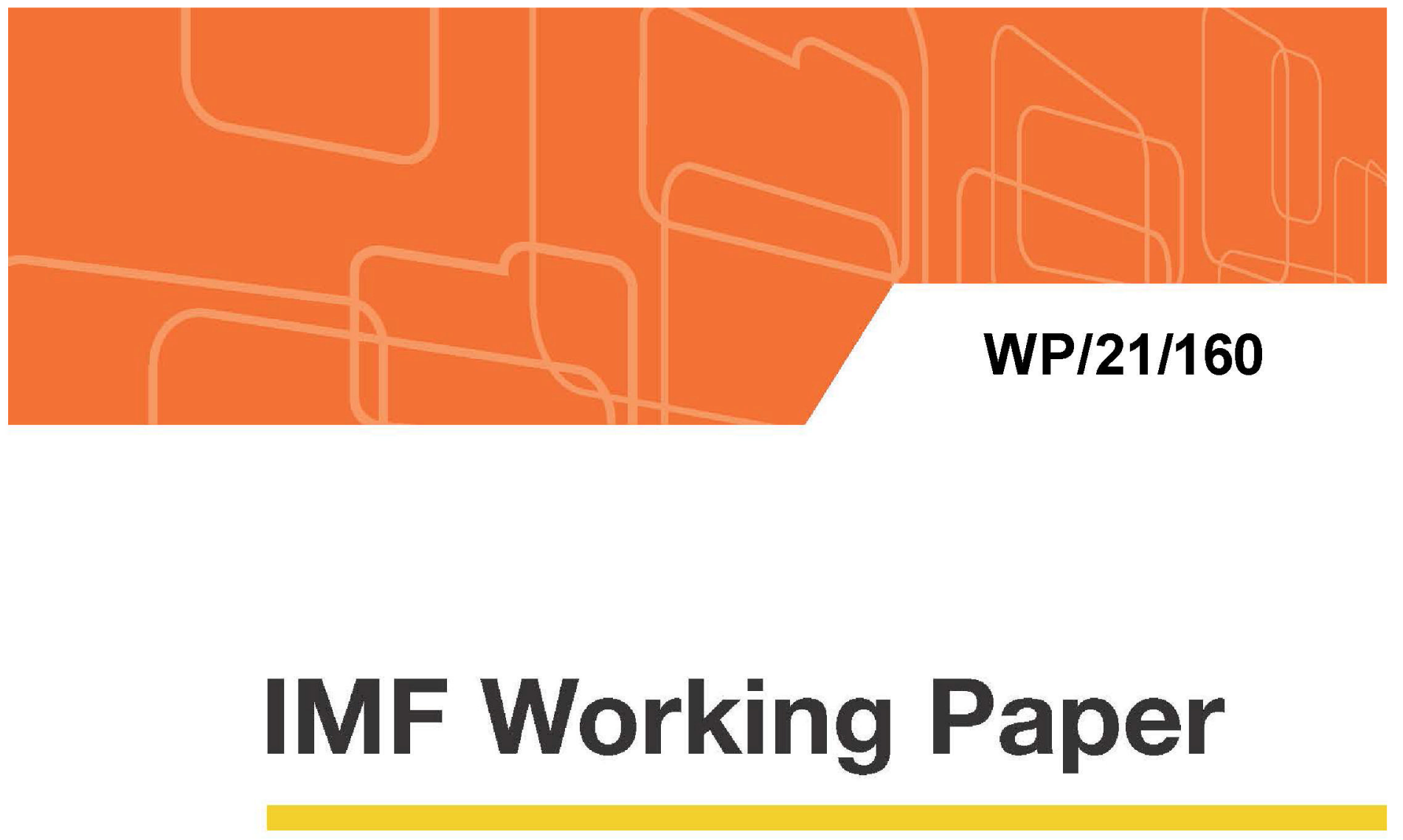

\title{
Chinese Investment in Latin America: Sectoral Complementarity and the Impact of China's Rebalancing
}

by Ding Ding, Fabio Di Vittorio, Ana Lariau and Yue Zhou

IMF Working Papers describe research in progress by the author(s) and are published to elicit comments and to encourage debate. The views expressed in IMF Working Papers are those of the author(s) and do not necessarily represent the views of the IMF, its Executive Board, or IMF management. 


\title{
IMF Working Paper
}

Western Hemisphere Department

\section{Chinese Investment in Latin America: Sectoral Complementarity and the Impact of China's Rebalancing}

\author{
Prepared by Ding Ding, Fabio Di Vittorio, Ana Lariau and Yue Zhou ${ }^{1}$
}

Authorized for distribution by Krishna Srinivasan

June 2021

IMF Working Papers describe research in progress by the author(s) and are published to elicit comments and to encourage debate. The views expressed in IMF Working Papers are those of the author(s) and do not necessarily represent the views of the IMF, its Executive Board, or IMF management.

\begin{abstract}
Over the last decade China's investment in Latin America and the Caribbean (LAC) has increased substantially in volume and become more diversified from natural resources to other industries. Using cross-border mergers and acquisitions data, we demonstrate that since mid-2010s China's overseas investment has tilted toward sectors where China has a comparative advantage in the global markets, a trend similar to that of other major foreign direct investment (FDI) source countries. Moreover, China's rising overseas investment can be linked to the rebalancing of Chinese economy, and LAC stands to benefit from its complementarity vis-à-vis China in sectors where the rising Chinese overseas investment can be met with LAC's own investment gaps. The COVID-19 pandemic could have a long-lasting impact on global value chains and FDI flows, which poses both challenges and opportunities to LAC in attracting FDI, including from China, to support the region's long-run economic development.
\end{abstract}

JEL Classification Numbers: F21, F23, G34

\footnotetext{
${ }^{1}$ The authors are gra teful for the comments from Diego Cerdeiro, Rishi Goyal, Weicheng Lian, Jorge Roldos, Krishna Sriniva san and participants of the IMF Western Hemisphere Department (WHD) seminar. All errors of the paper a re of the authors.
} 
Keywords: Foreign Direct Investment, Mergers and Acquisitions, China's Rebalancing, Latin America and the Caribbean

Authors' E-Mail Addresses: DDing@,imf.org; FDiVittorio@,imf.org;

ALariauBolentini@,imf.org; yzhou14@worldbank.org. 


\section{INTRODUCTION}

The surge in China's capital exports to the rest of the world since the turn of the century has transformed the international financial landscape. Once the world's largest destination of FDI, China has emerged as an important source of international financing especially for developing countries that have traditionally relied on capital from the Western world. China's rising overseas investment, while welcomed by the recipient countries, has also been met with suspicions that the investment surge might be driven by China's geopolitical objectives more than commercial interests, and the lack of data transparency could add to debt distress concerns of some recipient countries (e.g., Hurley et al. 2018; Horn et al. 2019; O'Connor 2019).

In this paper we zero in on China's investment in Latin America and the Caribbean (LAC), a region that has traditionally received FDI mostly from the advanced economies. Over the last two decades, China has shown a growing interest to strengthen its economic and financial linkages with LAC, first through trade and then followed by investment. ${ }^{2}$ When considered as a whole, the percentage of LAC's exports to China of its total exports increased from 1.3 percent in 2000 to 14.5 percent in 2020 . The stock of Chinese investment in LAC as a share of China's total overseas investment stock, after remaining stable for most of the early 2000 s, increased from 12 percent in 2014 to a peak of 21.4 percent in 2017.

As China ramps up its investment in LAC, the composition of the investment also experienced a major transformation in the last decade. Once heavily concentrated in fossil fuels, metals, agriculture and other natural resources, Chinese investment in LAC has increasingly tilted towards manufacturing and services industries such as transport, electricity, financial services and information and communication technology (ICT). ${ }^{3}$ The electricity generation and distribution sector, in particular, has become a major target of Chinese investment, with more than a dozen acquisition deals across LAC with an average size over US\$1 billion. Not even the intensification of the U.S.-China trade frictions could dampen China's investment spree in this area. In October 2019, the State Grid Company of China purchased Chiquinta Energia, the third largest electricity distributor in Chile, for US\$3 billion. Two months later, China Yangtze Power International acquired Luz del Sur, the largest electricity company in Peru, for US\$3.6 billion. Both acquisitions were among the largest FDI ever received by Chile and Peru. ${ }^{4}$

What are the factors behind China's rising investment in LAC and the transformation of its investment strategy in the region? Understanding the drivers of these developments,

\footnotetext{
${ }^{2}$ See Aa sa avari et a l. (2020, IMF) on the growing tra de linkages between China and LAC.

${ }^{3}$ Avendano et al. (2017) provide a comprehensivereview of the evolution of Chinese investment in LAC.

${ }^{4}$ Both Chiquinta Energia and Luz del Sur were previously owned by Sempra Energy, a U.S. Fortune 500 company.
} 
especially at the micro-level, can shed light on China's expanding role in global finance - an issue that is still under debate in the academic and policy arenas - and provide insights into the future of China-LAC economic and financial linkages.

According to the traditional literature on the drivers of international capital flows (e.g., Calvo et al. 1993; Bruno and Shin 2015), both push and pull factors can be at play. On the one hand, China's national strategy of liberalizing capital flows and expanding its footprint in global finance, most notably through the Belt and Road Initiative (BRI), is an important push factor. In LAC alone, China has set up three regional funds since 2015 to back up its investment in LAC: the China-LAC Industrial Cooperation Investment Fund (CLAI Fund) with a size of US $\$ 30$ billion; the China-LAC Cooperation Fund (CLAC Fund) of US $\$ 10$ billion; and the Special Loan Program for China-Latin America Infrastructure of US $\$ 20$ billion (Myers and Ray 2021). The global financial cycle in the last decade also played a role in supporting Chinese corporations' overseas borrowing, which in turn financed some of their overseas investment (Ding et al., 2019). On the other hand, given the large size of Chinese overseas investment, commercial viability has to be an important consideration for Chinese corporations. Pull factors, such as market conditions, institutional and regulatory frameworks of FDI destination countries, and the quality of local infrastructure and labor force, would also matter in attracting Chinese investment.

In this paper, we demonstrate that the rising volume and changing composition of Chinese investment in LAC can be associated with the sectoral complementarity between China and LAC, a pattern that is also observed in FDI of the major advanced economies. Moreover, this sectoral complementarity can be linked to China's ongoing efforts to reduce domestic excess capacity as its economy rebalances from an investment- and manufacturing-driven growth to a consumption- and services-driven growth. In fact, capacity reduction is one of the key elements of the Supply-Side Structural Reforms launched by the Chinese government in 2015 to guide the transition of the Chinese economy to a "new normal" (Chen et al., 2018).

To the extent that domestic excess capacity has affected profitability and growth prospects, a shift toward overseas markets for investment opportunities becomes a natural choice for Chinese corporations, especially the large state-owned enterprises (SOE) that often have the mandates of keeping asset expansion and supporting national development strategies such as capacity reduction and the BRI.

To illustrate this connection, consider the electricity sector as an example. In response to the 2008-09 Global Financial Crisis, the Chinese government embarked in massive infrastructure investment across major sectors of the economy including utilities. As a result, China's electricity generation capacity has risen sharply from 4.2 thousand TWh in 2010 to 7.2 thousand TWh in 2018. (In comparison, the capacity of the U.S. remained at 4.2 thousand TWh during the same period.) By mid-2010s, however, this rapid buildup of electricity generation capacity had started weighing on domestic investment, and the country's large electricity companies (most of them SOEs) looked abroad for investment opportunities as the domestic market shrank (Figure 1, left panel). By 2018, the top five Chinese state-owned 
electricity companies had completed overseas acquisitions for US\$18 billion, three times the value of their domestic acquisitions.

As the Chinese electricity companies were looking for overseas investment opportunities, LAC saw a growing demand in primary energy. ${ }^{5}$ While electricity consumption in LAC has grown steadily in the last decades, the average per capita electricity consumption has remained at only 50 percent of that in China and 25 percent of that in OECD countries (Figure 1, right panel). Investment gaps are believed to be a main constraint to faster development in the sector (Ruiz Nunez and Wei 2015; Castellani et al. 2019). Chinese investment, whether through acquisitions or joint ventures, can indeed help fill these gaps.

The rest of the paper is organized as follows. In section II we report stylized facts about the recent trends of China's FDI and overseas mergers and acquisition (M\&A) activities. In Section III we conduct empirical analysis on the push and pull factors behind the increase in China's overseas M\&A, with a focus on its investment in LAC and the sectors where there is domestic excess capacity. In Section IV, we discuss the policy implications in the postCOVID-19 environment.

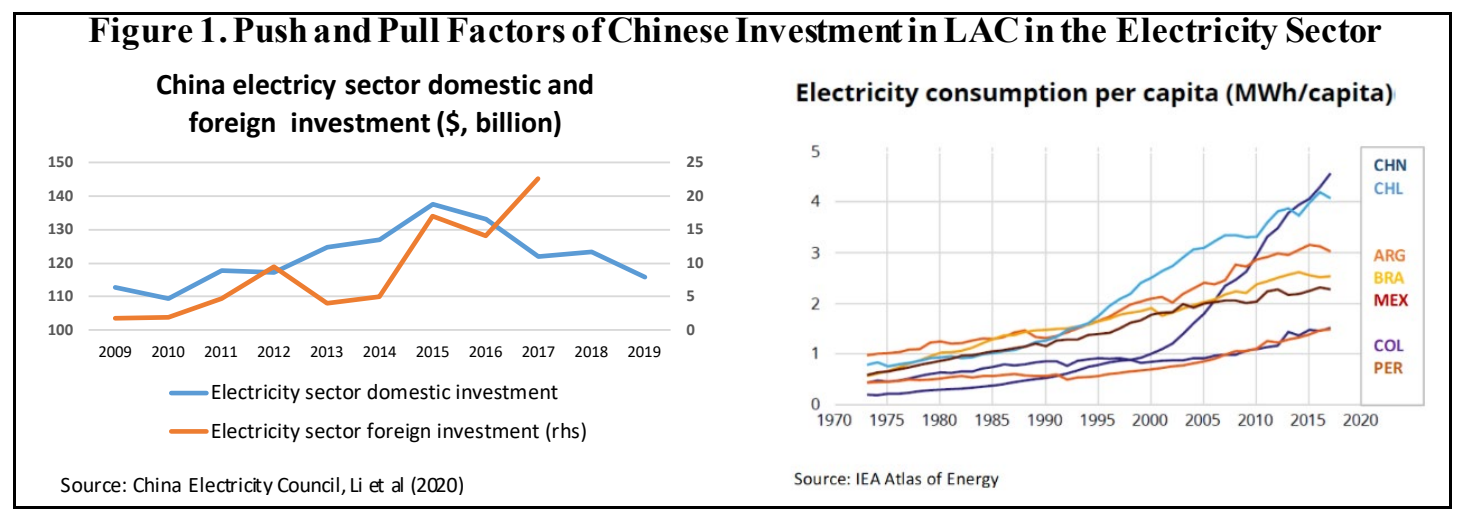

\section{RECENT TRENDS OF CHINESE OVERSEAS INVESTMENT}

In this section we present stylized facts about China's FDI on two dimensions: destination and sector. The analysis by destination is based on FDI data from China's Ministry of Commerce (MOFCOM), the IMF's Coordinated Direct Investment Survey (CDIS), the United Nations Conference on Trade and Development (UNCTAD) and the Economic Commission for Latin America and the Caribbean (ECLAC). As will be discussed later, there are large discrepancies across these aggregate data sources. To bypass these discrepancies, we use transaction-based M\&A data from Thomson Reuters for our sectoral level empirical analysis.

\footnotetext{
${ }^{5}$ Prima ry energy sources a re those obtained directly from nature, such as hydroelectricity, wind, and solar or those from extraction, such a soil, na tural ga s and coal (Tissot, 2012).
} 


\section{A. Chinese Investment by Destination}

Chinese FDI outflows have surged in the past two decades from negligible levels in the early 2000 s to US\$140-200 billion a year since 2015. According to the official data published by MOFCOM, Asia remains as the primary destination of Chinese FDI, while only a small share of Chinese FDI goes to LAC. In 2019, LAC attracted US\$6.4 billion FDI from China, accounting for 5 percent of China's total outward FDI (Figure 2, left panel). Out of this total, US $\$ 4.3$ billion were registered as outflows to offshore financial centers (OFCs) in the Caribbean, including Cayman Islands, British Virgin Island, and The Bahamas, which in most cases were not the final destination of the FDI (Figure 2, right panel).
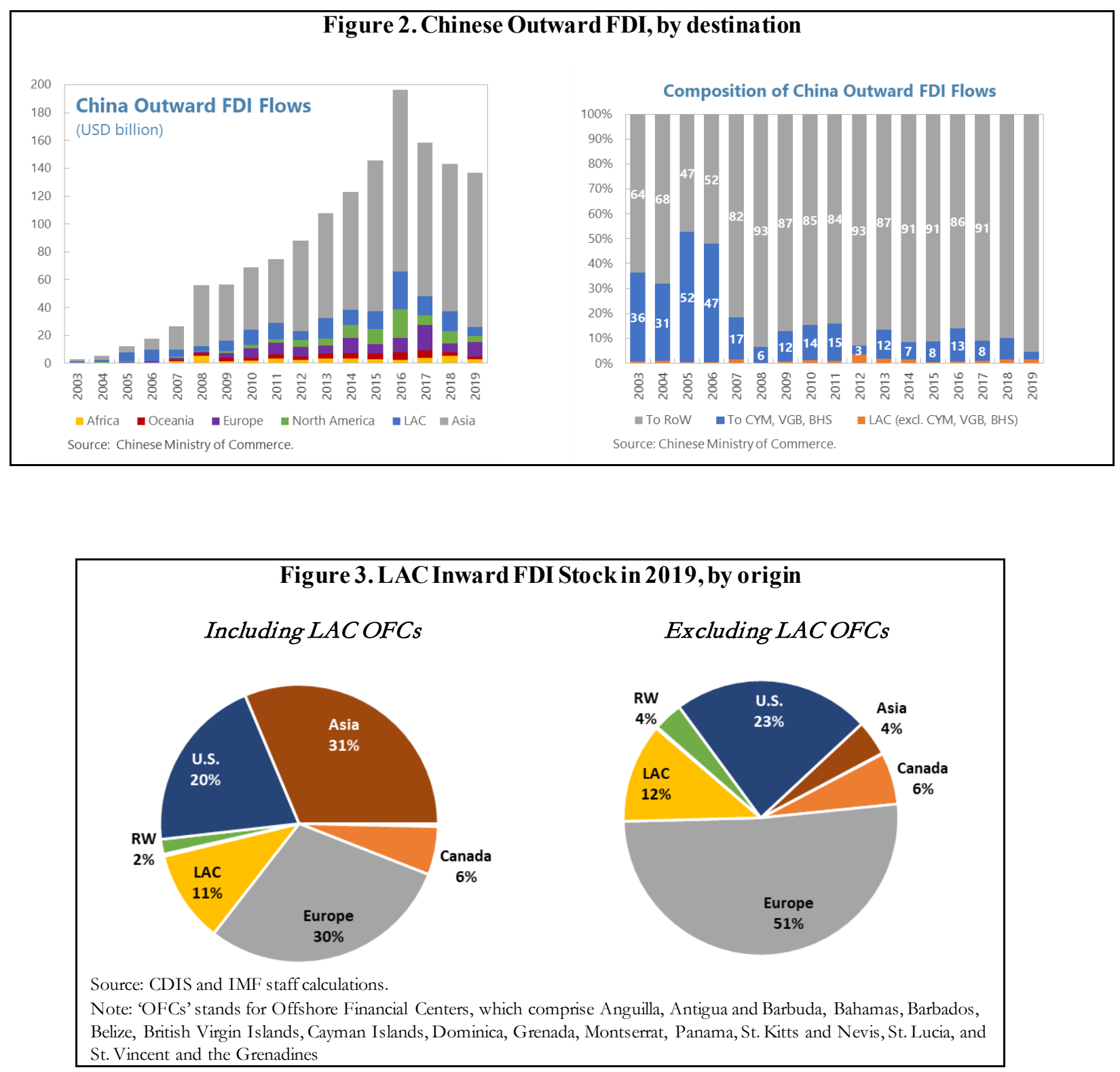
From LAC's perspective, when including OFCs, Asia — and particularly China — accounts for almost a third of LAC's inward FDI stock, followed by Europe and the U.S., with shares of 30 and 20 percent, respectively (Figure 3). When excluding OFCs, however, the share of Asia in LAC's inward FDI stock accounts for just 4 percent, indicating that a large portion of Asian investment to the region is channeled through OFCs.

There are, however, large discrepancies among the Chinese FDI statistics from different sources (Figure 4, left panel), which represents a well known challenge in the literature (Ortíz Velásquez 2016a and 2016b; Red ALC-China 2017). Most of the discrepancies stem from the treatment of OFCs, which is particularly relevant in the case of LAC given that OFCs are the main destination of Chinese FDI to the region according to the official statistics. To overcome this challenge, in the rest of the paper we focus our analysis on the transactionbased data on cross-border M\&A obtained from Thomson Reuters. The transaction-based M\&A data not only is able to mimic the trends of the official FDI statistics from the MOFCOM (Figure 4, right panel), but also keeps track of the final destination of each M\&A transaction, thus avoiding misreporting of FDI flows to OFCs.

Both the MOFCOM FDI stock data (after accounting for OFCs) and the transaction-based M\&A data indicate that Brazil is the main destination of Chinese investment (Figure 5). Chinese M\&A in Brazil almost doubled from US\$12.5 billion in 2011-14 to US\$23 billion in 2015-18, or about 5 percent of Brazil's GDP in 2018. The MOFCOM data also indicate that Venezuela, Argentina, Ecuador and Peru are important destinations of Chinese FDI; this is however not reflectd in the M\&A transaction-based data, possibly because the MOFCOM data covers all types of transactions, not only M\&A activities.

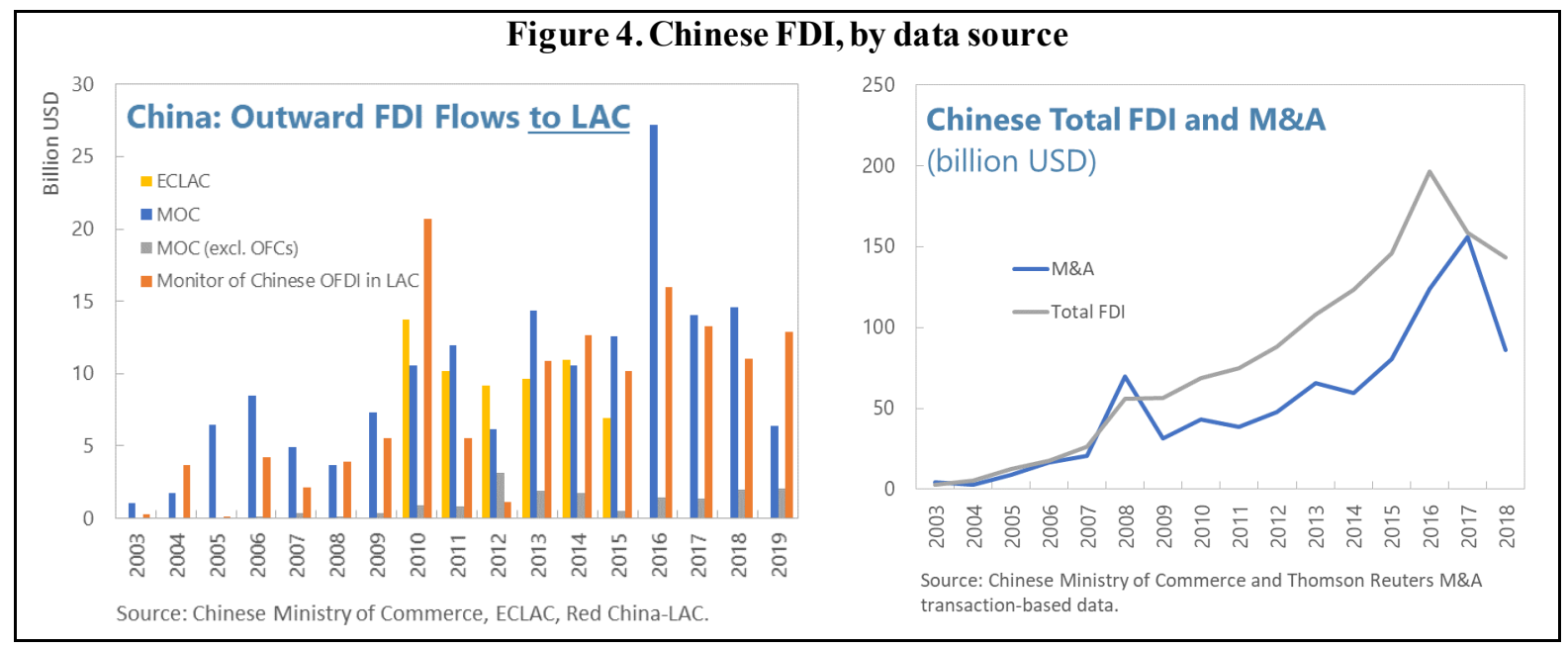




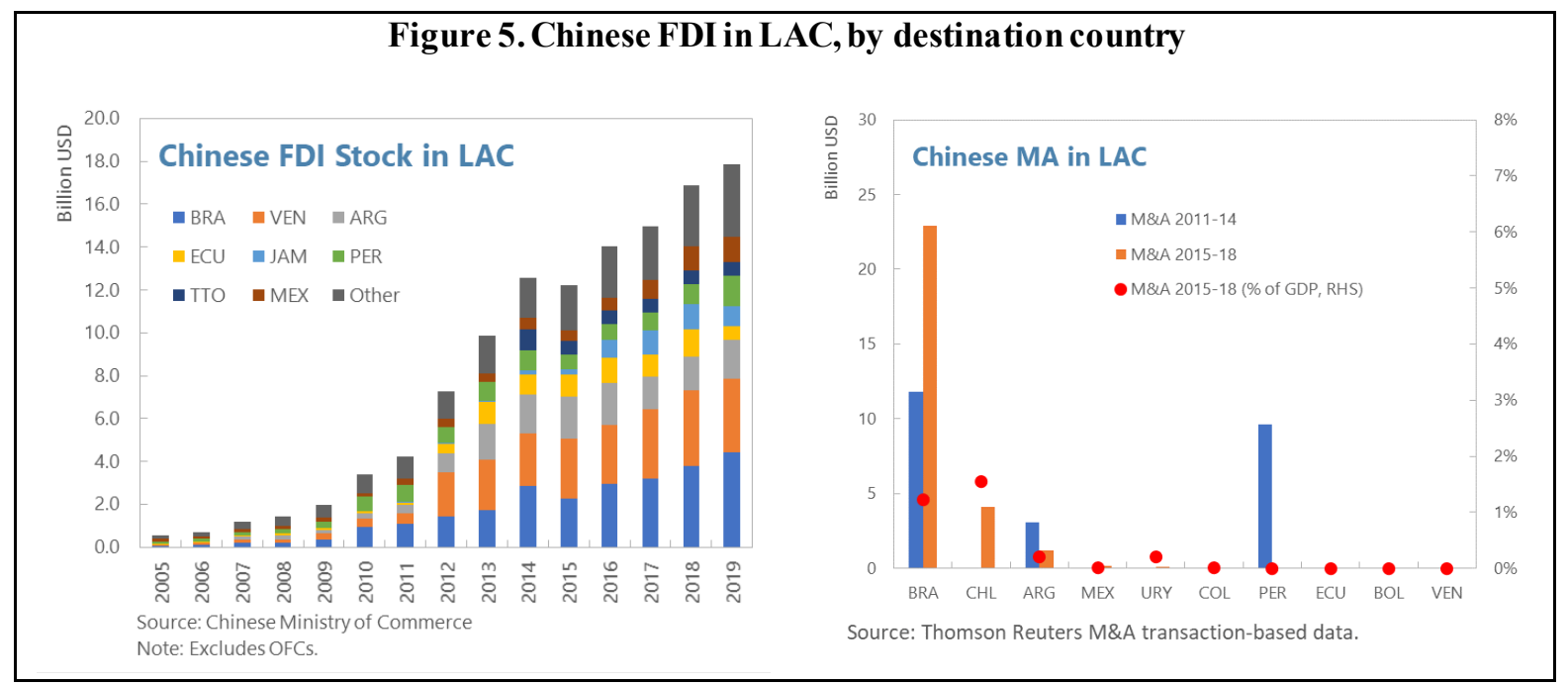

\section{B. Chinese Investment by Sector}

The transaction-based M\&A data indicates that during 2001-18, Chinese investment in LAC had a high concentration in the basic material and energy sector (Table 1). Not surprisingly, this was driven by China's growing demand for commodities, a major exports of LAC, and its strategy to shore up natural resources to fuel the country's booming economy (Avendano et al 2017).

\begin{tabular}{|c|c|c|c|c|c|c|c|}
\hline \multicolumn{8}{|c|}{ Table 1. Chinese M\&A, by sector and destination } \\
\hline & EAP & ECA & LAC & MENA & NA & SAR & SSA \\
\hline \multicolumn{8}{|c|}{ Average deal value (US\$ million, 2001-18) } \\
\hline Basic Materials \& Energy & 146 & 990 & 1,067 & 691 & 492 & 59 & 585 \\
\hline Consumer & 147 & 359 & 61 & 433 & 354 & 144 & 28 \\
\hline Financials & 222 & 597 & 144 & 67 & 826 & 45 & 1,063 \\
\hline Health and Technology & 91 & 257 & 33 & 416 & 169 & 246 & \\
\hline Industrials & 114 & 196 & 404 & 21 & 45 & 26 & 7 \\
\hline Telecommunication Services & 1,840 & 147 & & & 182 & 284 & \\
\hline Utilities & 604 & 943 & 1,305 & & 589 & & \\
\hline \multicolumn{8}{|c|}{ Number of deals (2001-18) } \\
\hline Basic Materials \& Energy & 355 & 107 & 41 & 17 & 126 & 6 & 42 \\
\hline Consumer & 373 & 148 & 22 & 5 & 107 & 5 & 2 \\
\hline Financials & 352 & 64 & 28 & 3 & 44 & 5 & 6 \\
\hline Health and Technology & 240 & 94 & 5 & 12 & 180 & 5 & 0 \\
\hline Industrials & 272 & 159 & 15 & 6 & 61 & 7 & 2 \\
\hline Telecommunication Services & 24 & 4 & 0 & 0 & 5 & 1 & 0 \\
\hline Utilities & 25 & 14 & 14 & 0 & 5 & 0 & 0 \\
\hline $\begin{array}{l}\text { Source: Thomson Reuters M\&A t } \\
\text { Note: EAP =East Asia and Pacific } \\
\text { East and North Africa; NA=Nort }\end{array}$ & $\begin{array}{l}\text {-based } \\
\text { urope a } \\
\text { a; SAR= }\end{array}$ & $\begin{array}{l}\text { entral A } \\
\text { th Asia; }\end{array}$ & $\begin{array}{l}\mathrm{AC}=\mathrm{L} \\
=\mathrm{Sub}-\mathrm{S}\end{array}$ & $\begin{array}{l}\text { America at } \\
\text { ran Africa. }\end{array}$ & $\mathrm{Car}$ & ; MEN & Ciddle \\
\hline
\end{tabular}


Over time, however, Chinese overseas investment has become more diversified across sectors. Before 2013, more than half of Chinese overseas M\&A (in terms of value) were in the basic material and energy sector (Figure 6, left panel). The surge of Chinese overseas M\&A since 2013, however, was almost evenly distributed among consumer goods, financial services, industrial goods, telecommunication services and utilities. In LAC, the surge mostly took place in the utility sector (Figure 6, right panel).

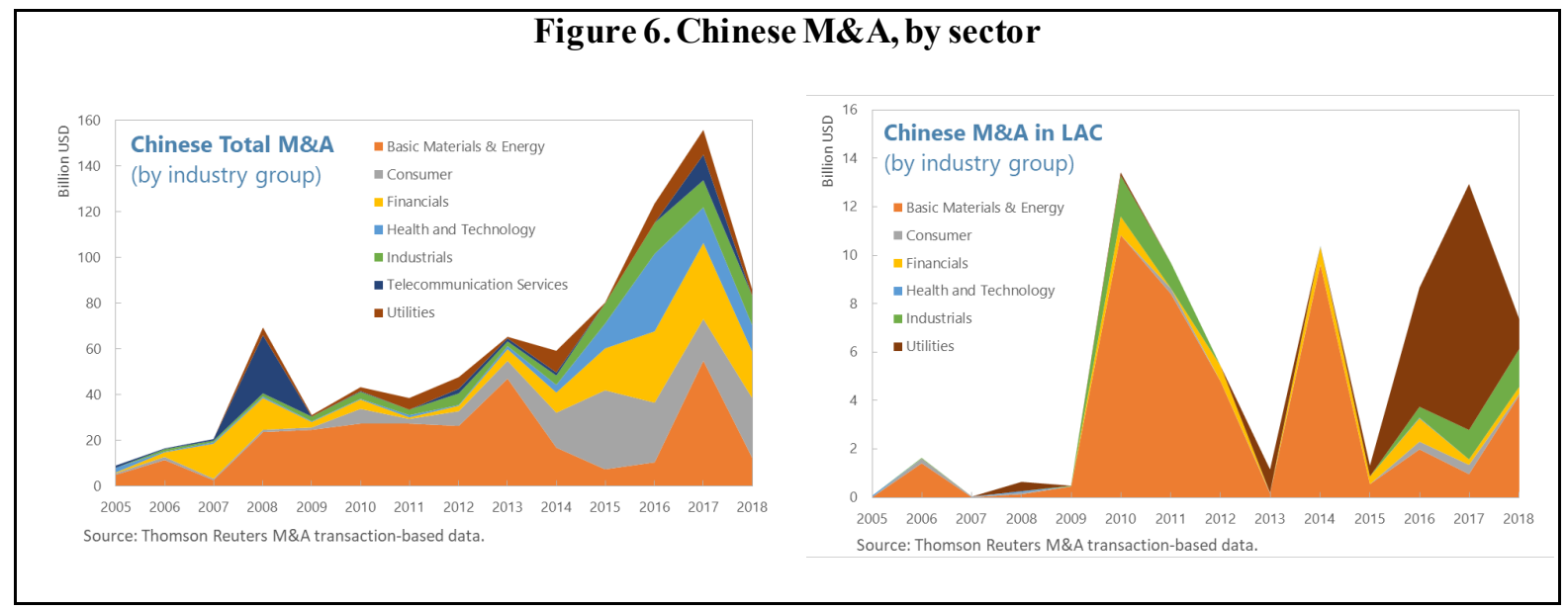

\section{M\&A Activities and Sectoral Competitivness}

To help contextulize the shifting trends of Chinese overseas investment at the sectoral level, we use the concept of revealed comparative advantage (RCA). The RCA index was first introduced by Balassa (1965) and is defined as follows:

$$
R C A_{i s}=\frac{E_{i s} / \sum_{s \in S} E_{i s}}{\sum_{j \in J} E_{j s} / \sum_{j \in J, S \in S} E_{j s}}
$$

where $E_{i s}$ denotes the exports of goods from sector $s$ by country $i$. The numerator of the RCA index is the share of a country's total exports in the sector of interest in its total exports. The denominator is share of world exports of the same sector in total world exports. Therefore, RCA indicates the proportion of a country's export of a certain good relative to the rest of the world. A country is said to have a revealed comparative advantage in a certain sector if the RCA value exceeds unity. When compared to each other, countries that have a higher value of RCA in a certain sector are better at producing goods/services in that sector than those with a lower value of RCA. As shown in Table 2, LAC has relatively high RCA in basic materials and energy while China has high RCA in utilities, consumer goods and 
telecom services. The advanced economies in Europe and North America stand out for their high RCA in industrial goods and financial services. ${ }^{6}$

\begin{tabular}{|c|c|c|c|c|c|c|c|c|}
\hline & EAP & ECA & LAC & MENA & NA & SAR & SSA & $\mathrm{CHN}$ \\
\hline Basic Materials \& Energy & 0.76 & 1.08 & 1.71 & 1.40 & 1.02 & 1.30 & 1.80 & 0.59 \\
\hline Consumer & 0.93 & 1.01 & 0.70 & 0.43 & 0.79 & 2.09 & 1.24 & 1.40 \\
\hline Financials & 0.76 & 1.07 & 0.92 & 0.74 & 1.34 & 0.42 & 0.58 & 0.31 \\
\hline Health and Technology & 0.70 & 0.99 & 1.25 & 1.60 & 0.62 & 3.01 & 0.57 & 1.04 \\
\hline Industrials & 0.90 & 1.07 & 0.83 & 1.08 & 1.19 & 0.45 & 0.33 & 0.88 \\
\hline Telecommunication Services & 1.04 & 0.96 & 0.72 & 0.82 & 1.15 & 0.92 & 0.78 & 1.18 \\
\hline Utilities & 2.01 & 0.61 & 0.96 & 0.36 & 0.71 & 0.23 & 0.09 & 1.92 \\
\hline Transportation & 1.21 & 1.02 & 0.99 & 1.29 & 0.68 & 0.73 & 1.78 & 0.91 \\
\hline
\end{tabular}

How does China's overseas M\&A relate to its RCA and to those of the destination countries? As shown in Figure 7, Chinese M\&A during 2011-14 was concentrated, both overall and in LAC, in the basic materials and energy sector, where China had low RCA. However, in the period of 2015-18, China has increased its M\&A in sectors where China has relatively high RCA, such as consumer goods, telecommunication services and, particularly, utilities (where LAC has low RCA).

To put such a transformation into context, we also compute the RCA index for a pool of other major M\&A source countries (for LAC as well as for the rest of the world) including Canada, France, Japan, Spain, the U.K. and the U.S. As shown in Figure 8, total overseas M\&A of these countrieshave a high concentration, in general, in sectors where these economies have a relatively high RCA, regardless of the RCA of the recipient countries. The exception is the sector of basic materials, where LAC has a high RCA while the M\&A source countries generally have a low RCA. A comparison between Figure 7 and Figure 8 seems to suggest that the sectoral distribution of Chinese overseas M\&A resembles that of the advanced economies after 2015. In the next section we conduct empirical analysis to draw the connection between M\&A and the RCA indices of both source and destination countries.

\footnotetext{
${ }^{6}$ Despite the widespread use of the RCA index in tra de literature, it has some drawbacks. Since RCA is based on pa st export values, it does not capture imports, nor ca n it predict the future trends. Moreover, RCA measures the rela tive importance of an industry for a country vis-à-vis the rest of theworld, but a country can have comparative advantage even though it occupies a small sha re of the export basket. RCA is a lso sensitive to the number of exported goods - if a country exports only a few products, their share in the export basket will be high as compared to a country that diversifies.
} 


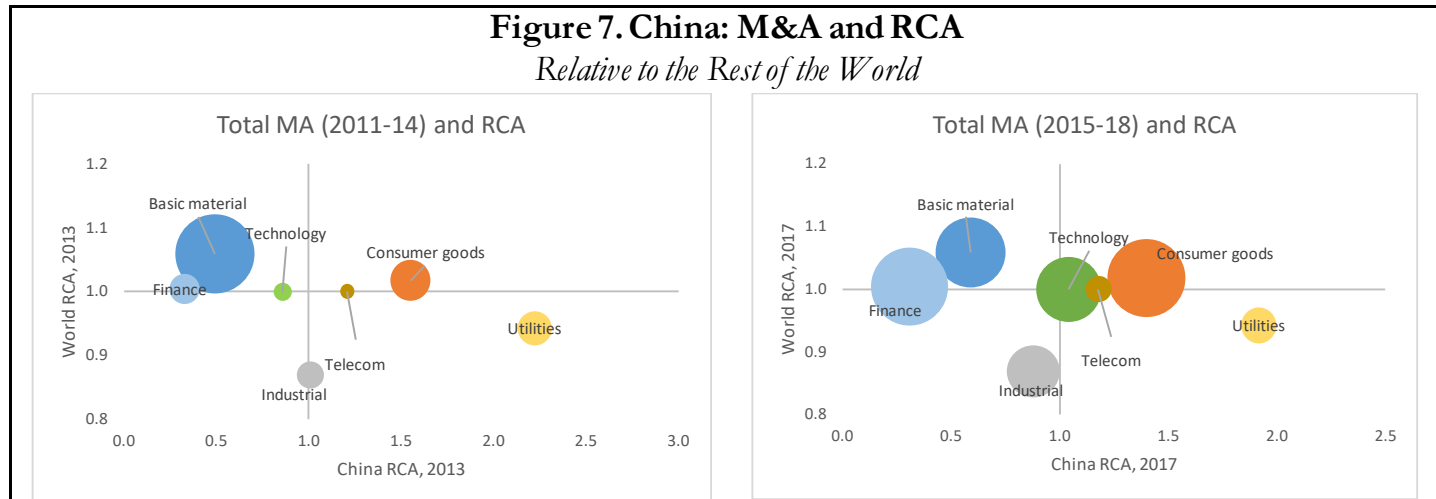

Relative to $L A C$
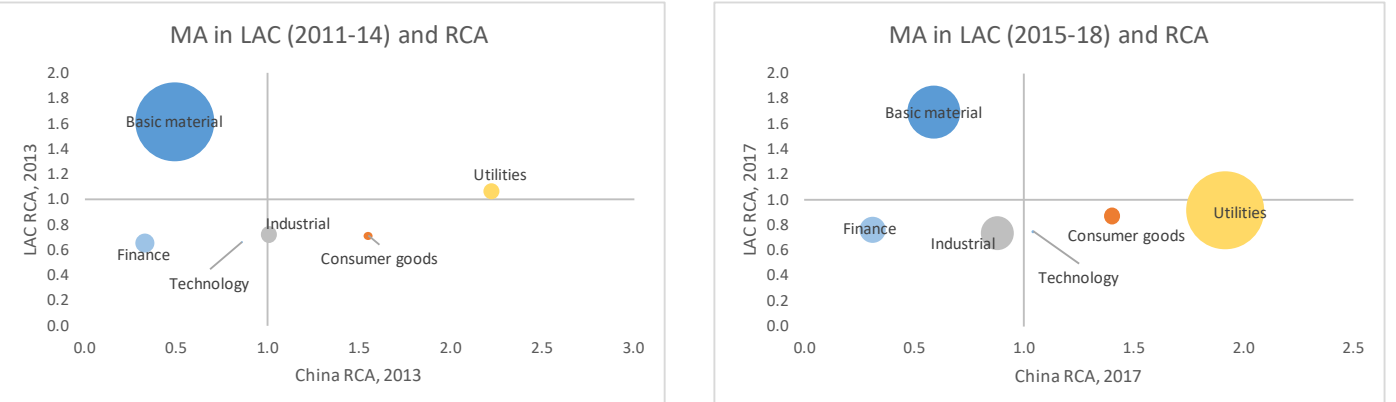

Source: Thomson Reuters transaction-based M\&A dataset, WITS, and IMF International Trade in Services.

Note: The size of the bubbles represents the total value of M\&A transactions in that particular sector.

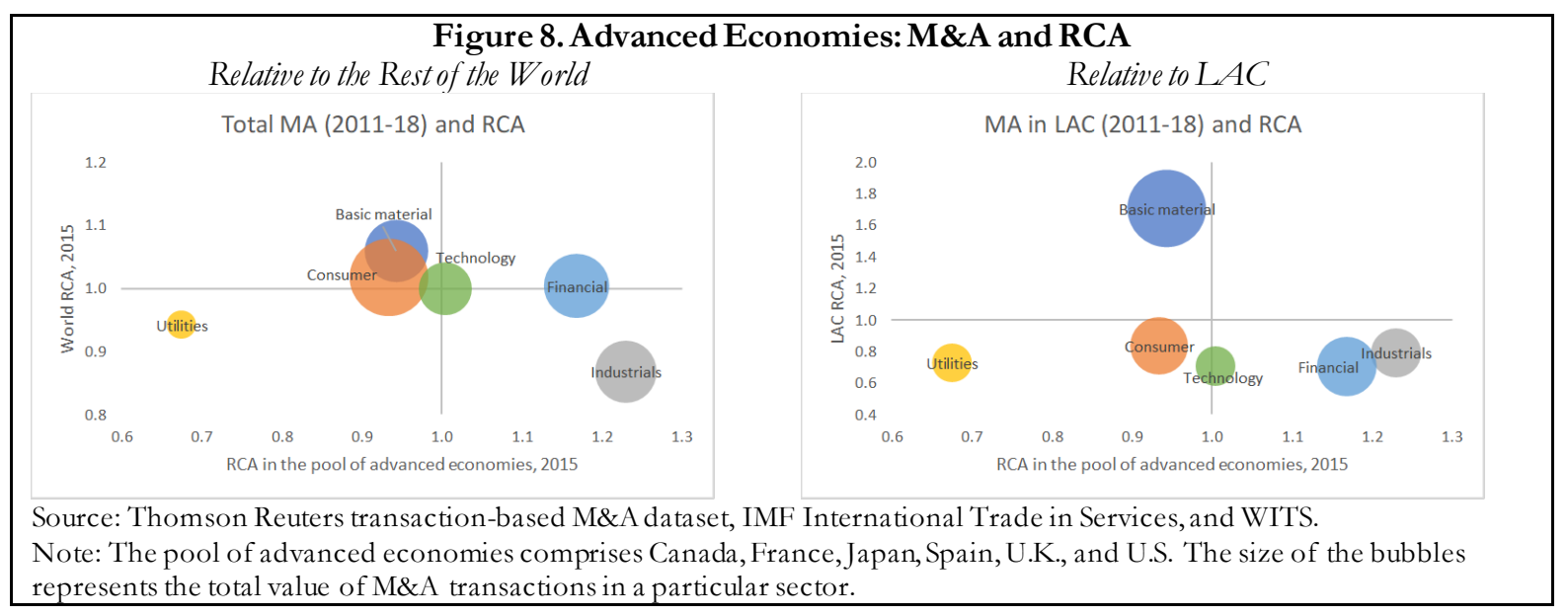




\section{EMPIRICAL ANALYSIS}

\section{A. Empirical Specification}

To evaluate the role of various push and pull factors in driving Chinese overseas M\&A, we estimate the following model: ${ }^{7}$

$$
M A_{i j s t}=\beta_{0}+\beta_{1} R C A_{s t}^{C N}+\beta_{2} R C A_{j s t}+\beta_{3} X_{j t}+\alpha_{j}+\alpha_{s}+\alpha_{t}+\varepsilon_{i j s t} .
$$

where $M A_{i j s t}$ is a dummy that takes the value 1 if a Chinese firm $i$ makes an M\&A transaction in country $j$, in sector $s$, in year $t ; R C A_{s t}^{C N}$ is the RCA of China in sector $s$, in year $t$ (which is common to all firms $i$ ); and $R C A_{j s t}$ is the RCA of destination country $j$, in sector $s$, in year $t . X_{j t}$ is a set of destination-year controls aimed at capturing other pull factors, including: (i) macro characteristics that proxy demand potential and macroeconomic stability (GDP growth, inflation rate, real effective exchange rate); (ii) measures of institutional environment; and (iii) pre-existence of a relationship with China (measured by the bilateral trade volume with China). The regression also controls for destination, sector and time fixed effects. In particular, the RCA index captures the extent to which a country is better than the rest of the world at producing goods/services in a certain sector. As shown in Agarwal et al (2020), the RCA index can help explain China's international portfolio equity allocations. ${ }^{8}$

As a robustness check, we also replace industry FE with firm FE to control for firm-specific factors. As the dependent variable is defined as a dummy variable, the above specification captures the 'extensive margin' of Chinese M\&A activities. We also analyze the 'intensive margin' of Chinese M\&A activities by replacing the dummay variable with the deal values.

\section{B. Data Description}

The empirical analysis is done using M\&A transaction-level data obtained from Thompson Reuters. ${ }^{9}$ As discussed previously, the benefit of this dataset is that it identifies the final destination of the M\&A operation, thus overcoming the challenges imposed by the OFCs. The dataset includes the following information for each transaction: acquiring (origin)

\footnotetext{
${ }^{7}$ The model specification is in line with Fuest et al.(2019) and Aga rwal et al. (2020).

${ }^{8}$ Aga rwalet al (2020) found that Chinese institutional investors are biased to wards sectors in which China has a comparative disadvantage and the destination countries have a comparative a dvantage in their foreign portfolio allocations.

${ }^{9}$ Many studies in the litera ture, such as Fuest et al. (2019), used the Bureau van Dijk Zephyr database. Bollaert and Dela nghe (2015) find that the Thomson Reuters dataset might be superior due to two main shortcomings of the Zephyr dataset: (i) continuous overwriting of firm-level da ta; and (ii) inaccuracies in announcement dates. The limitation of the Thomson Reuters dataset is that it does not include financial information about thetarget and a cquirer companies, while the Zephyr dataset does through its connection to Orbis.
} 
country, target (or destination) country, value of the deal, industry of the acquiring company, industry of the target company.

The sample covers the period 2001-2018 and comprises all the M\&A transactions originated in China as well as Canada, France, Japan, Spain, the U.K. and the U.S, the main sources of M\&A for LAC (and the rest of the world). There are 18 LAC countries where M\&A transactions have taken place during the period under study. ${ }^{10}$ The total number of transactions in the dataset is 74,824 of which 70,283 deals by the 6 industrial countries and 4,541 deals by China from 2001 to 2018 - with an average deal value of US\$280 million (Table 1). Table A.6 in the Appendix summarizes the same information for the transaction with acquiring company from the pool of the advanced economies (i.e. Canada, France, Japan, Spain, the U.K., and the U.S.).

The main regressor is the RCA measure described in the previous section, which is computed at the sectoral level both for the origin and the destination countries. It is constructed using data from the World Bank's World Integrated Trade Solution (WITS) and the IMF International Trade in Services.

The macroeconomic controls - including real GDP growth, inflation rate and real effective exchange rate - are obtained from the World Bank's World Development Indicators (WDI). The institutional environment is proxied by the six components of the Worldwide Governance Indicators (WGI) produced by the World Bank, including: voice and accountability, political stability and absence of violence, government effectiveness, regulatory quality, rule of law and control of corruption. Bilateral trade volumes from WDI are used to capture the pre-existence of a relationship between the destination and the origin country.

\section{The Drivers of Chinese Overseas M\&A}

The results of our estimations are reported in Tables A.1-A.5 in the Appendix.

The first two columns in Table A.1 present the baseline results. The coefficient of $R C A^{\text {Dest }}$, which captures comparative advantage as a pull factor, is significant and positive. This suggests that, on average, the number of Chinese overseas $M \& A$ is higher in sectors where the destination country has a high $R C A$. The coefficient of $R C A^{C H}$, which captures the comparative advantage as a push factor, is significant and negative. This means that, on average, the number of Chinese overseas $M \& A$ is higher in sectors where China has a low $R C A$.

\footnotetext{
${ }^{10}$ The M\&A destinations in LAC comprised in the dataset are: Brazil, Bahamas, Barbados, Belize, British Virgin Islands, Cayman Islands, Dominican Republic, ElSalva dor, Jamaica, Trinidad and Tobago, Honduras, Chile, Argentina, Mexico, Uruguay, Colombia, Peru, Ecuador, Bolivia and Venezuela.
} 
In LAC, however, RCA seems to work differently in explaining China's M\&A activities. Column 2 reports the baseline regression augmented with two interaction terms: a dummy between $R C A^{C H}$ and LAC, and a dummy between $R C A^{\text {Dest }}$ and LAC. The coefficient of the first interaction term is significant and negative, suggesting that China is more likely to invest in sectors where LAC has a low RCA (such as the utility sector). The coefficient of the second interaction term is significant and positive, indicating that China is more likely to invest in sectors where China has high RCA. The results in columns 3 and 4 are based on the same specification as those of columns (1) and (2), but with a firm fixed effect (FE) instead of a sector FE as a robustness check. The results still hold after this change.

We also augment an interaction term between $R C A^{\text {Dest }}$ and $R C A^{C H}$ to test the non-linear effects. ${ }^{11}$ Column 7 uses the full sample while column 8 and 9 use two subsamples of different periods (2001-14 and 2015-18). The coefficients of the interaction term are significantly negative, suggesting a non-linear effect of $R C A^{C N}$ with respect to $R C A^{\text {Dest }}$. Considering the subperiod after 2014 in column 9, this means that an increase in China's comparative advantage in a sector will drive more Chinese overseas M\&A to the destination country if the latter has comparative disadvantage in the same sector.

The above results, however, change when we split the sample into two sub-periods. For the period of 2001-14 (column 5 of Table A.1), the coefficient for $R C A^{\text {Dest }}$ is positive and the one for $R C A^{C N}$ is negative. This means that, on average, before 2015 China was more likely to invest in sectors where it had low RCA and the destination country had high RCA. But for the period 2015-18 (column 6 of Table A.1) the signs flip: the coefficient for $R C A^{\text {Dest }}$ is positive and the one for $R C A^{C N}$ is negative, indicating that since 2015 China is more likely to invest in sectors where China has high RCA and the destination country has low RCA. In other words, Chinese M\&A can be associated with sectoral complementarity between China and the destination countries, but this complementarity seems to have shifted at the sectoral level as China tilts towards areas where it has a comparative advantage in the global markets. This shift is even more pronounced when we consider Chinese M\&A in LAC (see Figure 9). On the other hand, M\&A by the advanced economies (Canada, France, Japan, Spain, the U.K., and the U.S.) did not experience such a shift during the sample period.

We also repeat the above analysis for Chinese investment in other regions, including East Asia and Pacific (EAP), Europe and Central Asia (ECA), Middle East and North Africa (MENA), North America (NA), South Asia (SAR) and Sub-Saharan Africa (SSA), and discover that it is LAC that has witnessed the most drastic transformation of Chinese investment before and after 2015, as measured by the change of the coefficient of $R C A^{C H}$ for

\footnotetext{
${ }^{11}$ For the sakeof interpretation, we subtract $R C A^{\text {Dest }}$ and $R C A^{C H}$ by their mean values.
} 
the region-specific regressions (Table A.2). ${ }^{12}$ As shown in Figure 9, the change of the coefficient is the largest in LAC, followed by MENA and NA.

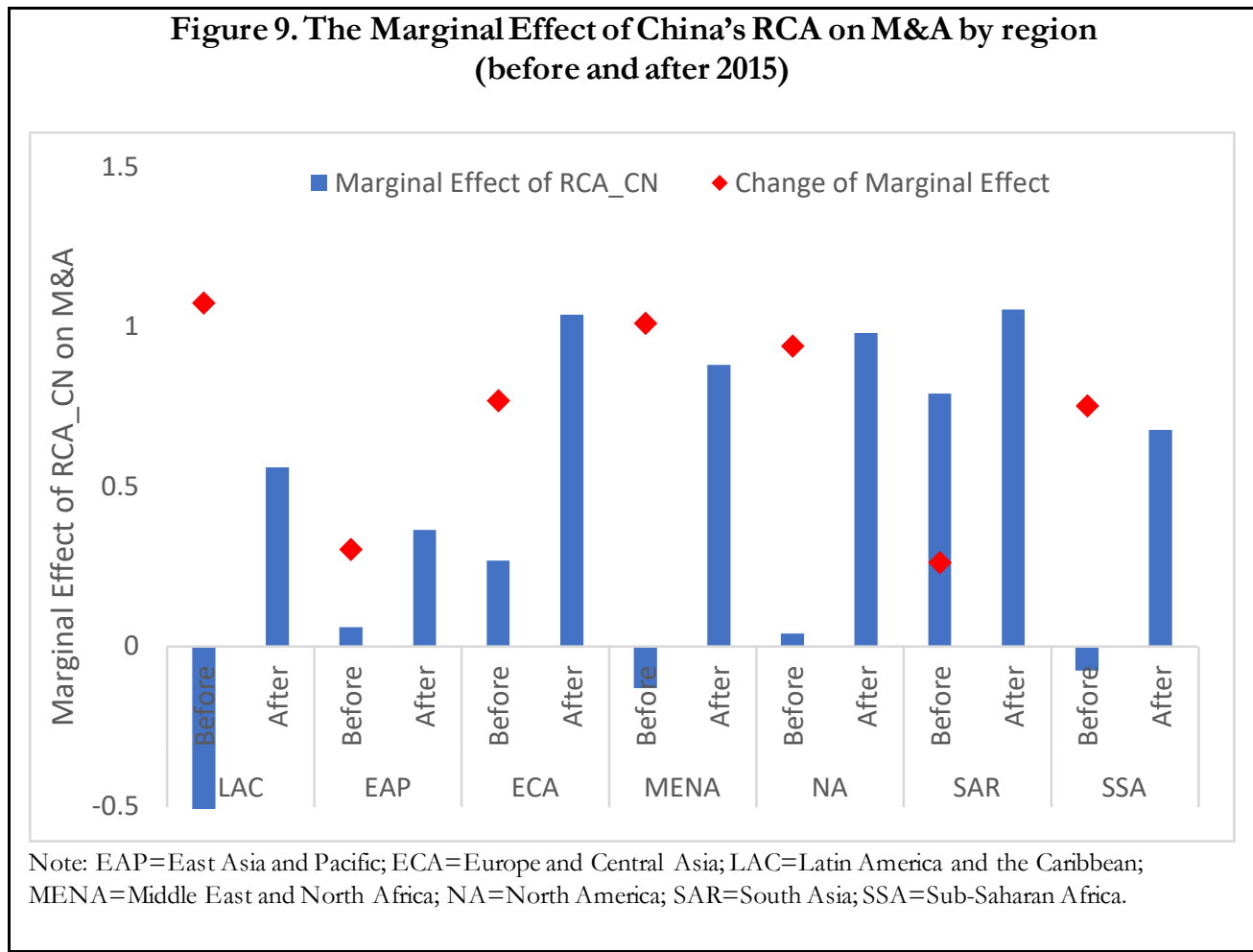

The regressions in Table A.1 and Table A.2 also incorporate a set of controls to capture other "pull factors" in destination countries. These include: (i) demand potential and macroeconomic stability; (ii) institutional environment; and (iii) pre-existing relations with China. The results are in line with IMF (2017).

- Macroeconomic variables. Chinese companies tend to invest in countries with faster growth, lower inflation, and a strengthening real effective exchange rate (REER).

- Institutional environment. Countries with stronger institutions tend to receive more Chinese M\&A than those with weaker institutions, at least along some dimensions of the insitutional environment. For example, rule of law has a positive and significant coefficient in all specifications. According to the WGI methodology, the rule of law

\footnotetext{
${ }^{12}$ The calculation is based on the regression in Table A.6. which is a extension of Table A.4. In the regression, we split the sample before and after 2015 and incorporate $R C A^{C H}$ and an interaction term between $R C A^{C H}$ and the region dummy on the right hand side. The marginal effect of $R C A^{C H}$ on M\&A for each region is, therefore, determined by the coefficient of $R C A^{C H}$ and the coefficient of the interaction term between $R C A^{C H}$ and the region dummy. For each subperiod, we ca lculate the marginal effect of $R C A^{C H}$ by adding the coefficients of the interaction term to the coefficients of $R C A^{C H}$. Then we calculate the change of the marginal effect of $R C A^{C H}$ after 2015 to quantitatively show the shift of China's overseas investment pattern in ea ch region.
} 
component "captures perceptions of the extent to which agents have confidence in and abide by the rules of society, and in particular the quality of contract enforcement, property rights, the police, and the courts, as well as the likelihood of crime and violence." Countries with better rule of law attract more investors by protecting them via the enforcement of a system of rules that are transparent and just.

- Pre-existing relations with China. The fact that the destination country was already exporting to China contributes positively to Chinese M\&A towards that country. This is consistent with the idea that trade is followed closely by FDI, as happened in the previous trade-growth cycle in 1970-90 led by Japan and South Korea (Khan et al., 2012). Once a market becomes known through trade relationships, it opens the door for investment opportunities, as investors become more aware and knowledgeable about the destination country. The opposite happens if the destination country had large imports from China.

Table A.3 replicates the regressions of Table A.1. but replaces the M\&A dummy with the $M \& A$ value to evaluate the 'intensive margin' of Chinese M\&A activities. The results are similar to those of the 'extensive margin' reported in Table A.1. In particular, as shown in columns 1-4, Chinese corporations, on average, tend to have higher-value $M \& A$ transactions in sectors where China has low RCA and the destination country has high RCA. When introducing the interaction terms to evaluate the specific case of LAC (columns 2 and 4), we find that higher-value $M \& A$ transactions in LAC tend to occur in sectors in which China has a high $R C A$. The impact of $R C A^{\text {Dest }}$, however, is less clear, as the coefficient on the interaction term is either not statistically significant in column 2 or significant and positive in column 4. The non linear effects of $R C A^{\text {Dest }}$ and $R C A^{C H}$ still hold at the intensive margin as shown in column 7-9.

When we split the sample into the two sub-periods, the results relative to the rest of the world for the intensive margin are in line with those for the extensive margin: since 2015 China tends to have higher-value $M \& A$ transactions in sectors where it has high RCA and the destination country has low RCA. When focusing on LAC, the regression results suggest that since 2015 China tend to have higher-value $M \& A$ transactions in sectors where either China or LAC has high RCA. These results are perhaps driven by the large size of the Chinese M\&A in LAC's commodity sector (where LAC has high RCA and China has low RCA) and utility sector (where LAC has low RCA and China has high RCA).

\section{How Does China Compare to the Other M\&A Source Countries?}

We also run the baseline regression for the pool of advanced economy M\&A source countries, and compare the coefficients associated with $R C A^{\text {Dest }}$ and $R C A^{\text {Origin }}$, as well as their interaction terms with the LAC dummy. These results are reported in Table A.4 in the Appendix, for the extensive and intensive margins of M\&A activity. Figure 10 summarizes the coefficients of interest from the extensive-margin regressions in Table A.4 (column 2) for the pool of advance countries of origin. The advanced economies tend to invest in sectors 
where the destination country has low RCA and the origin country has high RCA, as suggested by the negative (positive) sign and significance of the coefficient associated with $R C A^{\text {Dest }}$ ( $R C A^{\text {Origin }}$ ). When it comes to M\&A in LAC, the advanced economies tend to invest in sectors where either the home country or the destination country in LAC has high $R C A$. Overall, as shown in Figure 10, Chinese overseas M\&A resembles more the behavior of the advanced economies after 2015, both in LAC and in the rest of the destination countries.

Columns 3-4 in Table A.4 report the results of the intensive-margin regressions, based on the $M \& A$ value rather than the M\&A dummy. These results are consistent with those of the extensive margin; i.e. advanced economies tend to have larger $M \& A$ in sectors where the destination country has a low RCA and the origin country a high $R C A$. When adding the interaction terms with the LAC dummy, the one associated with the RCA of the country of origin becomes insignificant, but the one associated with the RCA of the destination country remains positive and significant, a result similar to that of the Chinese M\&A in LAC since 2015.

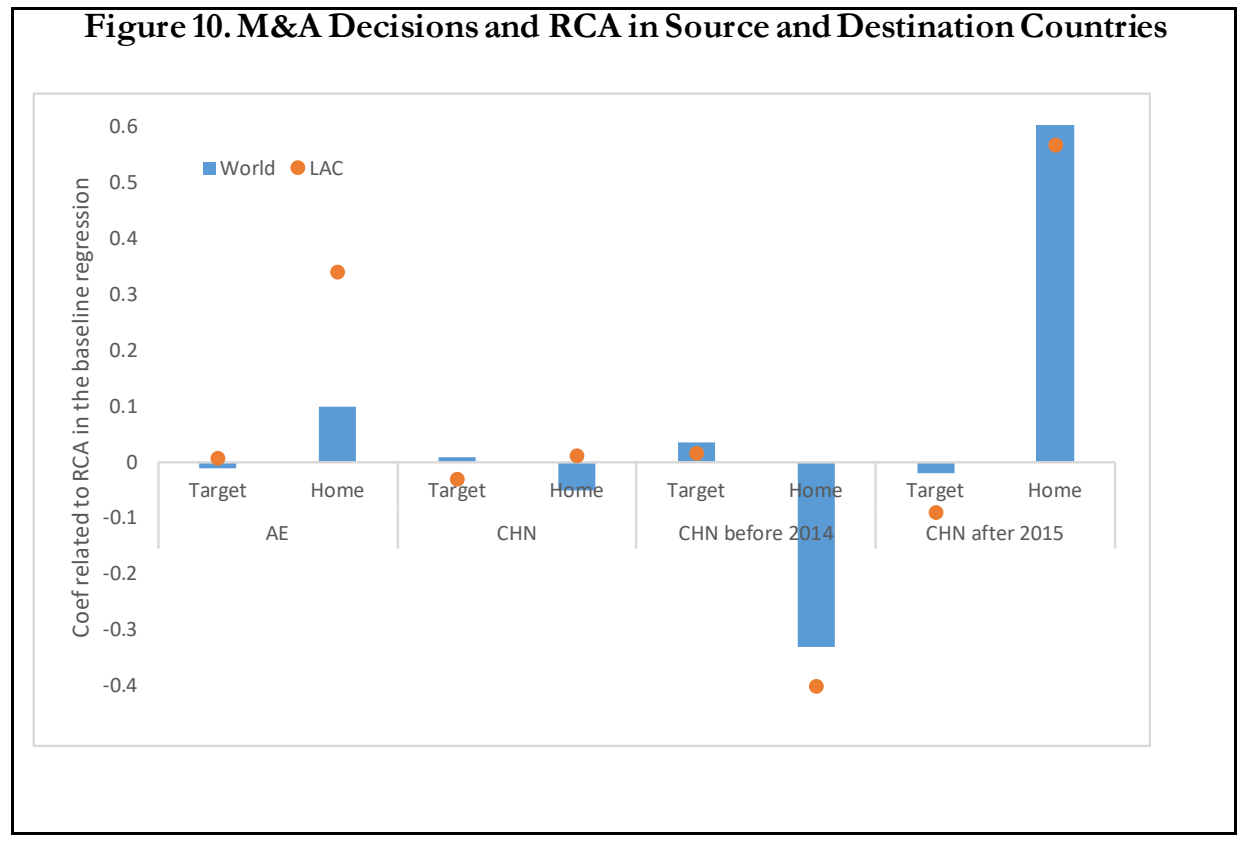

\section{E. The Impact of China's Rebalancing on FDI}

In the previous sections we have demonstrated that, while China used to have more overseas M\&A in sectors where it had low comparative advantage and the destination country had high comparative advantage, this composition has changed since the mid-2010s. China's investment behavior now resembles those of the advanced economies, with higher concentrations in sectors where China has high comparative advantage and the destination 
country has low comparative advantage. This pattern is observed in China's overseas investment in both LAC and other destinations.

Given that the transformation of China's overseas investment behavior took place in a relatively short period of time, it is unlikely that the transformation was caused by changing RCA at the sectoral level in China. Indeed, as shown in Figure 7, there were little changes in China's RCA across sectors before and after 2015-China has always been more competitive in sectors such as consumer goods, telecom and utilities while less competitive in sectors such as basic material and finance. What, then, prompted China to shift its overseas investment toward sectors where it is more competitive in the global markets?

As illustrated in the electricity sector example in Section I, this transformation seems to be associated with the rebalancing of the Chinese economy. In particular, years of overinvestment has led to buildup of excess capacity in certain sectors of the Chinese economy, much of which happens to be in sectors where China also demonstrates international competitiveness (Figure 11, left). While the causality between capacity accumulation and international comparative advantage is beyond the scope of this study, it is likely that China's export-driven growth model until the mid-2010s gave companies incentives to constantly expand capacities in sectors where their comparative advantage led to ever greater international market shares, which in turn reinforced such comparative advantages. However, as growth began slowing down in China, capacity utilization started to decline, putting pressure on corporate profitability. With limited room for to grow domestically, Chinese companies had to seek new markets to relocate capital and keep the pace of expansion, the latter an important consideration for the SOEs as they were often tasked to support governments at all levels to meet the growth targets. Indeed, there seems to be a negative correlation between China's overall capacity utilization index and the level of its overseas investment as shown in the right panel of Figure 11.

Ideally, we would like to use the sectoral capacity utilization measure to test whether the changing composition of China's overseas investment can be associated with the level of overcapacity at the sectoral level. However, as the disaggregation of capacity utilization by sector is only available starting from 2016, we use the cumulative investment in the past three years as a proxy for excess capacity at the sectoral level. ${ }^{13}$ The results are reported in Table A.5. The positive coefficient associated with the cumulative investment variable indicates that, on average, firms that made larger investments in the past three years are more prone to engage in overseas M\&A activities. The effect is even larger for China's investment

\footnotetext{
${ }^{13}$ Proxying excess ca pacity with cumulative investment has limitations. For in stance, a positive link between cumulative investment and M\&A activity abroad may not only reflect the need to offload excess capacity. It could be driven by a sudden increase in global demand that was initia lly covered through domestic investment and exports. However, the available data does not allow to disentangle these effects.
} 
in LAC, as evidenced by the positive and significant coefficient of the interaction term reported in columns 2 and 4.

As a robustness check, we also replace the cumulative fixed asset investment with sectorlevel average producer price index (PPI) growth in the past three years. ${ }^{14}$ The PPI measures the out-of-factory product prices, which reflect the demand from downstream clients or consumers. If PPI is high in an industry, it usually means that the industry is facing strong demand of its products and is less likely to have overcapacity. China's PPI experienced a prolonged period of negative growth from 2012 to mid-2015, likely reflecting overcapacity in certain sectors of the Chinese economy (Chen et al, 2018). When we use the PPI as an explanatory variable in the regressions, the main results still hold. China's rising overseas M\&A activities can be associated with declining PPI at the sector level, as shown in Columns 5-6 of Table A.5. In other words, domestic excess capacity is likely a contributing factor to China's rising overseas investment in the last decade.

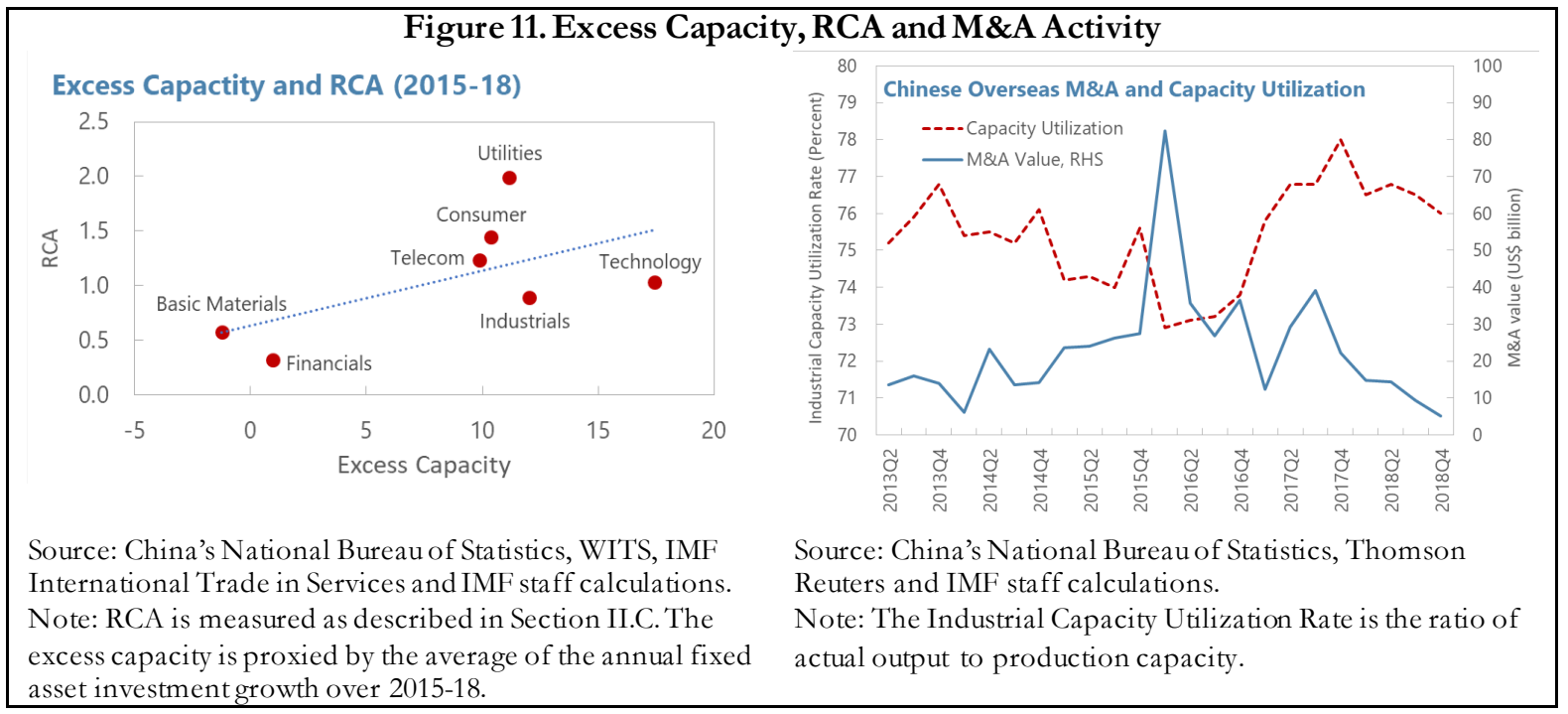

While overseas investment may serve the purpose for China to reduce its domestic overcapacity, it is also important to understand the benefits and costs that such investment may entail for the recipient countries. An aspect that has been discussed in the literature is the environmental footprint of Chinese investments, particularly in LAC. Ray and Gallagher (2016) argue that the historically high concentration in commodities - mostly metals and minerals - of Chinese investments in LAC may have had a negative environmental impact, including through higher greenhouse gas emissions and water use. However, as highlighted by Küblböck et al (2019), China and LAC have taken steps in recent years to limit the environmental footprint of these investments. The Chinese government has formulated

\footnotetext{
${ }^{14}$ PPI mea sures the out-of-factory product prices, which reflect the demand from downstreamclients or consumers. If the PPI is high in an industry, it means that the industry is facing strong demand of its products, and this it is less likely to have overcapacity. See Hu and Zhung (2016) for the connection between capacity utilization andPPI.
} 
guidelines to ensure that FDI meets environmental standards and regulation. In addition, both the China Development Bank and the Exim Bank of China include safeguards rules and implement ex-post environmental impact assessments in the projects they are involved. Furthermore, Li et al (2020) find that most of Chinese electric power investments in LAC is in the renewable energy sectors of hydropower and wind. Therefore, at least in the case of LAC, the more recent Chinese investments would contribute to the diversification of the energy matrix and the shift towards renewable sources of the destination countries, which would have a positive impact on environment.

\section{POLICY IMPLICATIONS AND THE IMPACT OF THE COVID-19 PANDEMIC}

In this paper we demonstrate that since mid-2010s China has shifted its overseas investment toward sectors where it has comparative advantage while the recipient countries are less competitive, a pattern that is also observed for other major FDI source countries. In other words, at the firm level China's overseas investment behavior is converging to the international norm that the FDI source countries try to exploit their comparative advantage in international trade vis-à-vis the recipient countries. ${ }^{15} \mathrm{We}$ also show that such a transformation can be linked to China's efforts to reduce its excess capacity, much of which has been accumulated in sectors where China has developed comparative advantage in the global markets over the years.

From LAC's perspective, given China's changing overseas investment behavior, there is scope to exploit the complementarity in other sectors besides utilities where China demonstrates comparative advantage and LAC the opposite. These sectors include consumer goods and telecom services, as indicated by their relative RCA indices in Table 2. Although the effects of FDI on productivity growth have been shown to be larger in the manufacturing sector than in services, the economic literature shows that brownfield investments could be more beneficial than greenfield investments in increasing domestic firms' productivity levels and growth across sectors (Du et al (2008), Jefferson (2002), Lin et at. (2008), Bartel and Harrison (2005), Arnold and Javorcik (2009)) and projects with shared domestic and foreign ownership generate larger vertical spillovers than fully foreign-owned subsidiaries (Javorcik and Spatareanu (2008)). To the extent that Chinese investment is also driven by its needs to relocate capital away from sectors with overcapacity domestically, LAC stands to benefit by directing Chinese investment to address LAC's own investment gaps. As shown in this paper, as well as in the related literature, a stable macroeconomic environment, favorable growth outlooks and strong institutional frameworks are also important pull factors of foreign investment.

\footnotetext{
${ }^{15}$ While our empirical results are based on M\&A data, the close correlation between Chines M\&A and FDI (Figure 4, right panel) suggests that these results ca n be applied to China's overall overseas investment.
} 
The future of the China-LAC investment linkage will also be affected by the long-term effects of the COVID-19 pandemic, which has severely impacted flows of FDI due to the sudden disruption of global supply chains, demand contractions and delayed investment owing to heightened economic uncertainty. Global FDI flows are estimated to have fallen by 42 percent to US $\$ 859$ billion in 2020 and are expected to remain weak in the near term. In terms of geographical distribution, the decline in 2020 was concentrated in developed economies, where FDI inflows fell by 69 percent. While all sectors have been affected, consumer cyclicals, such as airlines, hotels, restaurants and leisure, as well as manufacturing industries and the energy sector have experienced the largest declines. Going forward, UNCTAD expects any increases in global FDI flows in 2021 to come not from new investment in productive assets but from cross-border M\&As, especially in technology and healthcare ${ }^{16}$ As LAC markets (excl. OFCs) have become more reliant on FDI over the last decades, with annual inflows rising from US\$77 billion to US\$164 billion between 2005 and $2019,{ }^{17}$ the large decline of FDI inflows may have had dramatic consequences for LAC economic growth and could delay the region's recovery.

It is noteworthy that, against the global decline in FDI flows, China's outward FDI still increased by 3.3 percent in $2020 .{ }^{18}$ In this regard, China might be supporting counter-cyclical FDI in LAC countries, seizing opportunities for market share as U.S. and European investment in the region declines, contributing to consolidating a trend which started about a decade ago. However, the pace of China's economic recovery in the aftermath of the global pandemic may play a crucial role in the FDI flows. Demand for Chinese exports may fall in the absence of adequate policy support in advanced economies and China's own recovery prospects, global commodity prices, and the country's appetite for overseas investment may decline.

The pandemic hit at a time when corporate debt was at record levels and the stock of nonfinancial corporate bonds was at an all-time high at the end of 2019 (Celik at al., 2020). High levels of debt could limit the ability of Chinese companies to survive the COVID-19 crisis and support their foreign affiliates or pursue new investments. Rising debt levels and liquidity constraints could also be factors driving companies to divest some of their foreign operations (Borga et al, 2020).

Moreover, rising sovereign and corporate debt vulnerabilities in several LAC countries have been exacerbated by the global pandemic. Chinese investors could reduce their exposure to LAC to balance risks, thus generating large FDI outflows, including a sizable decline in the

\footnotetext{
${ }^{16}$ Investment Trends Monitor, Issue 38, UNCTAD, Ja nuary 2021. https://unctad.org/news/global-foreign-directinvestment-fell-42-2020-outlook-remains-weak.

${ }^{17}$ UNCTAD. 2020. World Investment Report. New York: United Nations.

${ }^{18}$ Source: http://www.xinhuanet.com/2021-01/22/c 1127010836.htm; http://www.gov.cn/xinwen/2020$\underline{07 / 16 / \text { content } 5527540 . h t m}$.
} 
number of M\&As and contribute to amplifying the economic fallout of the shock in the region. Moreover, Chinese FDI could also slow down because of China's slowing economic growth that has already forced its policy banks to be more selection on overseas projects, especially as some continue to struggle with some risky portfolios in Latin America, including potential losses in Venezuela. However, a robust rebound could strengthen Chinese state finance to the region as the policy banks disbursed loans to several LAC countries at concessional rates.

Potential structural changes to the global value chains (GVCs) in the post-pandemic world may also affect the prospects of Chinese overseas investment. China has positioned itself as one of the key players in global manufacturing since the early 1990 s by attracting investments through GVCs. During the COVID-19 pandemic, several scholars and policy makers have highlighted the fragility of GVCs and their role as shock amplifiers. A lockdown in one country could have disruptive consequences on the production process of other countries participating in the same value chain, leading to a large and persistent fall in output due to strong GVC's complementarities. The closure of factories in China at the end of January highlighted the reliance of many manufacturing value chains on inputs from China. ${ }^{19}$

The subsequent lockdowns executed all over the world resulted in a GVC disruption (Baldwin, 2020) and reignited a debate on the risks associated with international production. Several have recommended to strengthen GVCs by diversifying their supplier base or by onshoring part of the production processes (Javorcik, 2020). Others advocated the nationalization of GVCs as it could partially shield countries from the cost associated to any idiosyncratic shock along the value chain.

Therefore, companies may change the geographic allocation of their foreign operation in the aftermath of the global pandemic. Multinational enterprises (MNEs) may reorganize and shorten their GVCs to minimize supply-chain disruptions; alternatively, they could seek geographic diversification to improve crisis management of their supply chains by reducing exposure to specific shocks and risks. Such organizational changes of GVCs could have significant implications for China's economic prospects as MNEs account for a large share of global value-added, trade, employment and R\&D (Cadestin et al., 2018). The process could reduce demand for Chinese intermediate goods and cause a significant slowdown in Chinese international investments, by shifting the focus of Chinese investors from foreign to domestic markets. In addition, several MNEs have been considering transferring parts of their production platforms away from China. LAC countries could take advantage of this process, but so far, no LAC country appears in the Economic Prosperity Network proposed by the

\footnotetext{
${ }^{19}$ A survey of 628 U.S. companies, including 52 percent manufacturing and 48 percent non-manufacturing units, conducted by the Institute of Supply Management, revealed that nearly three-fourths of the companies had reported disruptions in their supply chains. Close to 57 percent responses reported longer lead times for components sourced from Tier-1 sources in China.
} 
U.S. through an alliance with trusted partners (the alliance so far would only include Australia, India, Japan, New Zealand, South Korea and Vietnam). In that regard, similar to the findings of Aasaavari et al (2020), China's position in the post-pandemic international trade and investment landscape poses both opportunities and challenges to LAC. 


\section{REFERENCES}

Aasaavari, N., Di Vittorio, F., Lariau, A., Li, Y., Mano, R., \& Rodriguez, P. (2020). China's Rebalancing: Opportunities and Challenges for LAC Exporters. IMF Working Paper 20/239. International Monetary Fund.

Agarwal, I., Gu, W., \& Prasad, E. S. (2020). The Determinants of China's International Portfolio Equity Allocations. IMF Economic Review, 68(3), 643-692.

Avendano, R., Melguizo, A., \& Miner, S. (2017). Chinese FDI in Latin America: New Trends with Global Implications. Atlantic Council and OECD Development Center.

Balassa, B. (1965). Trade Liberalisation and "Revealed" Comparative Advantage. The Manchester School, 33(2), 99-123.

Baldwin, R., \& Freeman, R. (2020). Trade conflict in the age of Covid-19. VoxEU.org (blog).

Bollaert, H., \& Delanghe, M. (2015). Securities Data Company and Zephyr, data sources for M\&A research. Journal of Corporate Finance, 33, 85-100.

Borga, M., Ibarlucea Flores, P., \& Sztajerowska, M. (2020). Drivers of divestment decisions of multinational enterprises - A cross-country firm-level perspective. OECD Working Papers on International Investment 2019/03. Paris: OECD Publishing.

Bruno, V., \& Shin, H. S. (2015). Cross-border banking and global liquidity. Review of Economic Studies, 82(2), 535-564.

Cadestin, C., De Backer, K., Desnoyers-James, I., Miroudot, S., Ye, M., \& Rigo, D. (2018). Multinational enterprises and global value chains: New Insights on the tradeinvestment nexus. OECD Science, Technology and Industry Working Papers, No. 2018/05. Paris: OECD Publishing.

Calvo, G. A., Leiderman, L., \& Reinhart, C. M. (1993). Capital Inflows and Real Exchange Rate Appreciation in Latin America: The Role of External Factors. IMF Staff Papers, 40(1), 108-151.

Castellani, F., Olarreaga, M., Panizza, U., \& Zhou, Y. (2019). Investment Gaps in Latin America and the Caribbean. International Development Policy $\mid$ Revue internationale de politique de développement, 11(1).

Çelik, S., Demirtaş, G., \& Isaksson, M. (2020). Corporate Bond Market Trends, Emerging Risks and Monetary Policy. OECD Capital Market Series. Paris: OECD Publishing.

Chen, L., Ding, D., \& Mano, R. (2018). China's Capacity Reduction Reform and its Impact on Producer Prices. International Monetary Fund, IMF Working Paper 18/216.

Ding, D., Huang, Y., \& Zhou, Y. (2019). China's Offshore Corporate Dollar Bonds. In A. Schipke, M. Rodlauer, \& L. Zhang (Eds.), The Future of China's Bond Market. Washington, D.C.: International Monetary Fund.

Fuest, C., Hugger, F., Sultan, S., \& Xing, J. (2019). Chinese Acquisitions Abroad: Are They Different? Center for Economic Studies (CES), CESifo Working Paper 7585.

Horn, S., Reinhart, C. M., \& Trebesch, C. (2019). China's Overseas Lending. NBER Working Paper 26050. NBER.

Hu, B., \& Zhuang, J. (2016). Knowledge Work on Excess Capacity in the People's Republic of China. Asia Development Bank.

Hurley, J., Morris, S., \& Portelance, G. (2018). Examining the Debt Implications of the Belt and Road Initiative from a Policy Perspective. CGD Policy Paper 121, Center for Global Development, Washington, DC. 
IMF. (2017). Drivers of Capital Flows and the Role of the Investor Base in Latin America. In Regional Economic Outlook: Western Hemisphere. Washington, D.C.: International Monetary Fund.

Javorcik, B. (2020). Global supply chains will not be the same in the post-COVID-19 world. En R. E. Baldwin, \& S. J. Evenett (Edits.), COVID-19 and Trade Policy, Why Turning Inward Won't Work (págs. 111-116). London: CEPR Press.

Kahn, T., Molina, D., Ramizo, D., Pesadilla, G., Burmeister, L., Mesquita Moreira, M., \& Wignaraja, G. (2012). Shaping the Future of the Asia-Latin America and the Caribbean Relationship. Inter-American Development Bank, Washington, D.C.

Küblböck, K., Tröster, B., \& Ambach, C. (2019). Going Global: Chinese Natural Resource Policies and their Impacts on Latin America. ÖFSE Briefing Paper, No. 24. Vienna: Austrian Foundation for Development Research (ÖFSE).

Li, Z., Gallagher, K. P., \& Mauzerall, D. L. (2020). China's global power: Estimating Chinese foreign direct investment in the electric power sector. Energy Policy, 136(C).

Myers, M., \& Ray, R. (2021). Shifting Gears: Chinese Finance in LAC, 2020. China-Latin America Report. Washington, DC: The Dialogue and BU Global Development Policy Center.

O'Connor, N. G. (2019). Made in China 2025: The Future of Manufacturing and Sourcing in China. China Supplier 1000 Project.

Ortíz Velásquez, S. (2016a). Conducta de la OFDI de China (2005-2014) según dos enfoques metodológicos: activo/pasivoy direccional. Monitor de la OFDI de China en ALC, Mexico.

Ortíz Velásquez, S. (2016b). Monitor de la OFDI de China en América Latina y el Caribe. Aspectos metodológicos. Monitor de la OFDI de China en ALC, Mexico.

Ray, R., \& Gallagher, K. P. (2016). China in Latin America: Environment and Development Dimensions. Revista Tempo do Mundo, 2(2), 131-154.

Red ALC-China. (2017). Monitor of Chinese OFDI in Latin America and the Caribbean. Retrieved from https://www.redalc-china.org/monitor/

Ruiz Nunez, F., \& Wei, Z. (2015). Infrastructure investment demands in emerging markets and developing economies. The World Bank, Policy Research Working Paper Series 7414.

Tissot, R. (2012). Latin America's Energy Future. Infrastructure and Environment Department, Discussion Paper No. IDB-DP-252. Washington, D.C.: Inter-American Development Bank. 


\section{APPENDIX: Tables}

Table A.1: M\&A Decision and RCA (extensive margin)

\begin{tabular}{|c|c|c|c|c|c|c|c|c|c|}
\hline & $\begin{array}{c}(1) \\
\text { Full }\end{array}$ & $\begin{array}{l}(2) \\
\text { Full }\end{array}$ & $\begin{array}{l}\text { (3) } \\
\text { Full }\end{array}$ & $\begin{array}{c}\text { (4) } \\
\text { Full }\end{array}$ & $\begin{array}{c}\text { (5) } \\
2001-14\end{array}$ & $\begin{array}{c}(6) \\
2015-18\end{array}$ & $\begin{array}{l}\text { (7) } \\
\text { Full }\end{array}$ & $\begin{array}{c}(8) \\
2001-14\end{array}$ & $\begin{array}{c}(9) \\
2015-18\end{array}$ \\
\hline & \multicolumn{9}{|c|}{ Dep Var: M\&A dummy } \\
\hline \multirow[t]{2}{*}{$R C A^{d e s t}$} & $0.007 * * *$ & $0.009 * * *$ & $0.007 * *$ & $0.009 * *$ & $0.036 * * *$ & $-0.026 * * *$ & $0.019 * * *$ & $0.023 * * *$ & 0.006 \\
\hline & $(0.003)$ & $(0.003)$ & $(0.004)$ & $(0.004)$ & $(0.004)$ & $(0.006)$ & $(0.003)$ & $(0.003)$ & $(0.006)$ \\
\hline \multirow[t]{2}{*}{$R C A^{C H}$} & $-0.047 * * *$ & $-0.050 * * *$ & $-0.075^{* * *}$ & $-0.076^{* * *}$ & $-0.338^{* * *}$ & $0.607 * * *$ & $-0.021 *$ & $-0.226 * * *$ & $1.207 * * *$ \\
\hline & $(0.012)$ & $(0.012)$ & $(0.005)$ & $(0.005)$ & $(0.052)$ & $(0.177)$ & $(0.012)$ & $(0.014)$ & $(0.181)$ \\
\hline \multirow[t]{2}{*}{$R C A^{d e s t} \times L A C$} & & $-0.046 * * *$ & & $-0.106 * * *$ & -0.028 & $-0.075^{* * *}$ & & & \\
\hline & & $(0.011)$ & & $(0.022)$ & $(0.018)$ & $(0.025)$ & & & \\
\hline \multirow[t]{2}{*}{$R C A^{C H} \times L A C$} & & $0.060 * * *$ & & $0.083^{* * *}$ & $-0.177 * * *$ & -0.047 & & & \\
\hline & & $(0.016)$ & & $(0.025)$ & $(0.026)$ & $(0.042)$ & & & \\
\hline \multirow[t]{2}{*}{$R C A^{d e s t} \times R C A^{C H}$} & & & & & & & $-0.027 * * *$ & $-0.035^{* * *}$ & $-0.046 * * *$ \\
\hline & & & & & & & $(0.004)$ & $(0.004)$ & $(0.011)$ \\
\hline \multirow[t]{2}{*}{ GDP growth } & $-0.005^{* * *}$ & $-0.005^{* * *}$ & $0.008^{* * *}$ & $0.008^{* * *}$ & 0.003 & -0.002 & $0.003 * * *$ & $0.004 * * *$ & $0.010^{* *}$ \\
\hline & $(0.001)$ & $(0.001)$ & $(0.001)$ & $(0.001)$ & $(0.003)$ & $(0.005)$ & $(0.001)$ & $(0.001)$ & $(0.005)$ \\
\hline \multirow[t]{2}{*}{ Inflation } & $-0.013^{* * *}$ & $-0.013 * * *$ & $-0.004 * * *$ & $-0.005^{* * *}$ & $0.021 * * *$ & $-0.012 * *$ & 0.001 & $0.006^{* * *}$ & $-0.026 * * *$ \\
\hline & $(0.002)$ & $(0.002)$ & $(0.001)$ & $(0.001)$ & $(0.004)$ & $(0.005)$ & $(0.002)$ & $(0.002)$ & $(0.005)$ \\
\hline \multirow[t]{2}{*}{ REER (-, depreciation) } & $0.001 * * *$ & $0.001 * * *$ & $0.000^{* *}$ & $0.000 * *$ & $0.004 * * *$ & $-0.005^{* *}$ & $0.004 * * *$ & $0.001 * * *$ & -0.001 \\
\hline & $(0.000)$ & $(0.000)$ & $(0.000)$ & $(0.000)$ & $(0.001)$ & $(0.002)$ & $(0.000)$ & $(0.000)$ & $(0.003)$ \\
\hline \multirow[t]{2}{*}{ Ln(export to China) } & $0.093 * * *$ & $0.093 * * *$ & 0.012 & 0.012 & $0.126^{* * *}$ & $0.138^{* *}$ & $0.064 * * *$ & $0.025^{* *}$ & $0.210^{* * *}$ \\
\hline & $(0.010)$ & $(0.010)$ & $(0.008)$ & $(0.008)$ & $(0.032)$ & $(0.059)$ & $(0.010)$ & $(0.011)$ & $(0.061)$ \\
\hline \multirow[t]{2}{*}{ Ln(import from China) } & $-0.048^{* * *}$ & $-0.048 * * *$ & $-0.071 * * *$ & $-0.071 * * *$ & $-0.101 * *$ & -0.104 & $-0.037 * * *$ & $-0.096 * * *$ & -0.066 \\
\hline & $(0.014)$ & $(0.014)$ & $(0.012)$ & $(0.012)$ & $(0.042)$ & $(0.073)$ & $(0.014)$ & $(0.016)$ & $(0.076)$ \\
\hline \multirow[t]{2}{*}{ Accountability } & $0.005^{* * *}$ & $0.005^{* * *}$ & $-0.002 * * *$ & $-0.002 * * *$ & -0.000 & 0.004 & $0.005^{* * *}$ & 0.001 & $0.010^{* *}$ \\
\hline & $(0.001)$ & $(0.001)$ & $(0.001)$ & $(0.001)$ & $(0.002)$ & $(0.004)$ & $(0.001)$ & $(0.001)$ & $(0.004)$ \\
\hline \multirow[t]{2}{*}{ Political stability } & $-0.005^{* * *}$ & $-0.005^{* * *}$ & $-0.001 * * *$ & $-0.001 * * *$ & $0.002 * *$ & 0.000 & $-0.001 * * *$ & $-0.002 * * *$ & $-0.003 * * *$ \\
\hline & $(0.000)$ & $(0.000)$ & $(0.000)$ & $(0.000)$ & $(0.001)$ & $(0.001)$ & $(0.000)$ & $(0.000)$ & $(0.001)$ \\
\hline \multirow[t]{2}{*}{ Governance } & 0.001 & 0.000 & $-0.001 *$ & $-0.001 *$ & $0.009 * * *$ & 0.003 & $-0.002 * * *$ & $0.002 * *$ & $-0.011 * *$ \\
\hline & $(0.001)$ & $(0.001)$ & $(0.001)$ & $(0.001)$ & $(0.002)$ & (0.004) & $(0.001)$ & $(0.001)$ & $(0.005)$ \\
\hline \multirow[t]{2}{*}{ Regulatory quality } & $-0.002^{* *}$ & $-0.002^{* *}$ & -0.000 & -0.000 & $-0.008^{* * *}$ & 0.001 & $-0.007 * * *$ & $0.005^{* * *}$ & $-0.013^{* * *}$ \\
\hline & $(0.001)$ & $(0.001)$ & $(0.001)$ & $(0.001)$ & $(0.002)$ & $(0.003)$ & $(0.001)$ & $(0.001)$ & $(0.003)$ \\
\hline \multirow[t]{2}{*}{ Rule of law } & $0.002^{* *}$ & $0.002 * *$ & $0.005^{* * *}$ & $0.005^{* * *}$ & 0.003 & 0.002 & $-0.006 * * *$ & $0.003^{* * *}$ & $0.007 *$ \\
\hline & $(0.001)$ & $(0.001)$ & $(0.001)$ & $(0.001)$ & $(0.003)$ & $(0.004)$ & $(0.001)$ & $(0.001)$ & $(0.004)$ \\
\hline \multirow[t]{2}{*}{ Control of corruption } & 0.001 & 0.001 & $-0.001 * *$ & $-0.001 * *$ & $-0.004 * *$ & 0.001 & $0.003^{* * *}$ & $-0.006^{* * *}$ & 0.001 \\
\hline & $(0.001)$ & $(0.001)$ & $(0.001)$ & $(0.001)$ & $(0.002)$ & $(0.005)$ & $(0.001)$ & $(0.001)$ & $(0.005)$ \\
\hline Firm FE & $\mathrm{N}$ & $\mathrm{N}$ & Y & Y & $\mathrm{N}$ & $\mathrm{N}$ & $\mathrm{N}$ & $\mathrm{N}$ & $\mathrm{N}$ \\
\hline Industry FE & $\mathrm{Y}$ & $\mathrm{Y}$ & $\mathrm{Y}$ & $\mathrm{Y}$ & $\mathrm{Y}$ & $\mathrm{Y}$ & $\mathrm{Y}$ & $\mathrm{Y}$ & $\mathrm{Y}$ \\
\hline Destination FE & $\mathrm{Y}$ & Y & $\mathrm{Y}$ & $\mathrm{Y}$ & $\mathrm{Y}$ & Y & Y & Y & $\mathrm{Y}$ \\
\hline Year FE & $\mathrm{Y}$ & $\mathrm{Y}$ & $\mathrm{Y}$ & $\mathrm{Y}$ & $\mathrm{Y}$ & $\mathrm{Y}$ & $\mathrm{Y}$ & $\mathrm{Y}$ & $\mathrm{Y}$ \\
\hline Obs & 44,386 & 44,386 & 44,355 & 44,182 & 33,641 & 10,540 & 44,266 & 33,652 & 10,736 \\
\hline R-square & 0.139 & 0.139 & 0.277 & 0.309 & 0.286 & 0.103 & 0.066 & 0.122 & 0.097 \\
\hline
\end{tabular}

Standard errors in parentheses

*** $\mathrm{p}<0.01,{ }^{*} * \mathrm{p}<0.05,{ }^{*} \mathrm{p}<0.1$ 
Table A.2: M\&A Decision and RCA (extensive margin) by region

\begin{tabular}{|c|c|c|c|c|c|c|c|c|c|c|c|c|}
\hline \multirow[b]{4}{*}{ VARIABLES } & (1) & (2) & (3) & (4) & (5) & (6) & (7) & (8) & (9) & (10) & (11) & $(12)$ \\
\hline & \multicolumn{2}{|c|}{ EAP } & \multicolumn{2}{|c|}{ ECA } & \multicolumn{2}{|c|}{ MENA } & \multicolumn{2}{|c|}{ NA } & \multicolumn{2}{|c|}{ SAR } & \multicolumn{2}{|c|}{ SSA } \\
\hline & $\begin{array}{c}\text { Before } \\
2015\end{array}$ & $\begin{array}{c}\text { After } \\
2015\end{array}$ & $\begin{array}{c}\text { Before } \\
2015\end{array}$ & $\begin{array}{c}\text { After } \\
2015\end{array}$ & $\begin{array}{c}\text { Before } \\
2015\end{array}$ & $\begin{array}{c}\text { After } \\
2015\end{array}$ & $\begin{array}{c}\text { Before } \\
2015\end{array}$ & $\begin{array}{l}\text { After } \\
2015\end{array}$ & $\begin{array}{c}\text { Before } \\
2015\end{array}$ & $\begin{array}{l}\text { After } \\
2015\end{array}$ & $\begin{array}{c}\text { Before } \\
2015\end{array}$ & $\begin{array}{l}\text { After } \\
2015\end{array}$ \\
\hline & \multicolumn{12}{|c|}{ Dep Var: MA dummy } \\
\hline \multirow[t]{2}{*}{$R C A^{\text {dest }}$} & $\begin{array}{c}- \\
0.011^{* * *}\end{array}$ & $-0.040 * * *$ & $0.005^{*}$ & 0.002 & $0.005^{* *}$ & 0.008 & -0.003 & $0.010^{*}$ & $0.006^{* *}$ & $0.011^{*}$ & $0.005^{*}$ & 0.009 \\
\hline & $(0.002)$ & $(0.005)$ & $(0.003)$ & $(0.005)$ & $(0.003)$ & $(0.006)$ & $(0.002)$ & $(0.005)$ & $(0.003)$ & $(0.006)$ & $(0.003)$ & $(0.006)$ \\
\hline \multirow[t]{2}{*}{$R C A^{C H}$} & $0.044 * * *$ & -0.159 & $-0.058^{* * *}$ & $0.709^{* * *}$ & $-0.071 * * *$ & $0.618^{* * *}$ & $-0.043^{* * *}$ & $0.672^{* * *}$ & $-0.071 * * *$ & $0.635^{* * *}$ & $-0.070^{* * *}$ & $0.650 * * *$ \\
\hline & $(0.012)$ & $(0.140)$ & $(0.013)$ & $(0.167)$ & $(0.014)$ & $(0.177)$ & $(0.012)$ & $(0.168)$ & $(0.014)$ & $(0.177)$ & $(0.014)$ & $(0.177)$ \\
\hline \multirow[t]{2}{*}{$R C A^{\text {dest }} \times D^{\text {region }}$} & $0.357 * * *$ & $0.243^{* * *}$ & $0.021 * * *$ & $0.127 * * *$ & $0.648 * * *$ & $0.221 * * *$ & $0.507^{* * *}$ & $0.330 * * *$ & $-0.246^{* * *}$ & $-1.095^{* * *}$ & $0.486^{* * *}$ & $0.651^{* * *}$ \\
\hline & $(0.006)$ & $(0.006)$ & $(0.006)$ & $(0.013)$ & $(0.078)$ & $(0.066)$ & $(0.011)$ & $(0.029)$ & $(0.077)$ & $(0.382)$ & $(0.030)$ & (0.193) \\
\hline \multirow[t]{2}{*}{$R C A^{C H} \times D^{\text {region }}$} & $0.104^{* * *}$ & $0.523^{* * *}$ & $0.326^{* * *}$ & $0.329 * * *$ & -0.060 & $0.263^{* * *}$ & $0.083^{* * *}$ & $0.309^{* * *}$ & $0.862^{* * *}$ & $0.419 * * *$ & -0.006 & 0.027 \\
\hline & $(0.007)$ & $(0.012)$ & $(0.011)$ & $(0.017)$ & $(0.122)$ & $(0.094)$ & $(0.013)$ & $(0.024)$ & $(0.202)$ & $(1.463)$ & $(0.075)$ & $(0.418)$ \\
\hline \multirow[t]{2}{*}{ GDP growth } & 0.001 & -0.004 & $-0.003 * * *$ & 0.002 & -0.002 & 0.002 & $0.003 * * *$ & 0.003 & -0.001 & 0.002 & -0.001 & 0.005 \\
\hline & $(0.001)$ & $(0.004)$ & $(0.001)$ & $(0.005)$ & $(0.001)$ & $(0.005)$ & $(0.001)$ & $(0.005)$ & $(0.001)$ & $(0.005)$ & $(0.001)$ & $(0.005)$ \\
\hline \multirow[t]{2}{*}{ inflation } & $0.007^{-} * * *$ & -0.003 & $-0.004 * *$ & $-0.017 * * *$ & $-0.005^{* * *}$ & $-0.012^{* *}$ & $-0.003^{*}$ & $-0.011^{* *}$ & $-0.005^{* * *}$ & $-0.011 * *$ & $-0.004 * *$ & $-0.009^{*}$ \\
\hline & $(0.001)$ & $(0.004)$ & $(0.002)$ & $(0.005)$ & $(0.002)$ & $(0.005)$ & $(0.001)$ & $(0.005)$ & $(0.002)$ & $(0.005)$ & $(0.002)$ & $(0.005)$ \\
\hline \multirow[t]{2}{*}{ REER } & $0.001 * * *$ & $0.011 * * *$ & $0.002 * * *$ & $0.004^{*}$ & $0.002 * * *$ & $0.010^{* * *}$ & $0.001^{* * *}$ & $0.009 * * *$ & $0.002^{* * *}$ & $0.010^{* * *}$ & $0.002^{* * *}$ & $0.010^{* * *}$ \\
\hline & $(0.000)$ & $(0.002)$ & $(0.000)$ & $(0.002)$ & $(0.000)$ & $(0.002)$ & $(0.000)$ & $(0.002)$ & $(0.000)$ & $(0.002)$ & $(0.000)$ & $(0.002)$ \\
\hline \multirow[t]{2}{*}{$\ln ($ export to China) } & 0.008 & $-0.120 * * *$ & $0.043 * * *$ & -0.059 & $0.060 * * *$ & $-0.139 * *$ & $0.042 * * *$ & $-0.155^{* * *}$ & $0.058^{* * *}$ & $-0.141^{* *}$ & $0.055^{* * *}$ & $-0.136^{* *}$ \\
\hline & $(0.009)$ & $(0.044)$ & $(0.010)$ & $(0.053)$ & $(0.010)$ & $(0.056)$ & $(0.009)$ & $(0.053)$ & $(0.010)$ & $(0.056)$ & $(0.010)$ & $(0.056)$ \\
\hline \multirow[t]{2}{*}{$\ln$ (import from China) } & -0.013 & 0.018 & 0.017 & -0.024 & $-0.029 * *$ & -0.047 & $-0.032^{* *}$ & -0.036 & $-0.025^{*}$ & -0.046 & $-0.025^{*}$ & -0.056 \\
\hline & $(0.013)$ & $(0.057)$ & $(0.015)$ & $(0.069)$ & $(0.015)$ & $(0.073)$ & $(0.013)$ & $(0.069)$ & $(0.015)$ & $(0.073)$ & $(0.015)$ & $(0.073)$ \\
\hline \multirow[t]{2}{*}{ accountability } & $0.004 * * *$ & $0.005^{*}$ & $-0.002 * * *$ & -0.004 & $-0.003^{* * *}$ & -0.004 & $-0.003^{* * *}$ & $-0.008^{* *}$ & $-0.003 * * *$ & -0.004 & $-0.003^{* * *}$ & -0.004 \\
\hline & $(0.001)$ & $(0.003)$ & $(0.001)$ & $(0.003)$ & $(0.001)$ & $(0.004)$ & $(0.001)$ & $(0.003)$ & $(0.001)$ & $(0.004)$ & $(0.001)$ & $(0.004)$ \\
\hline \multirow[t]{2}{*}{ political stability } & $0.004 * * *$ & -0.001 & $-0.004 * * *$ & -0.001 & $-0.005^{* * *}$ & -0.001 & $-0.003^{* * *}$ & 0.000 & $-0.005^{* * *}$ & -0.001 & $-0.005^{* * *}$ & -0.001 \\
\hline & $(0.000)$ & $(0.001)$ & $(0.000)$ & $(0.001)$ & $(0.000)$ & $(0.001)$ & $(0.000)$ & $(0.001)$ & $(0.000)$ & $(0.001)$ & $(0.000)$ & $(0.001)$ \\
\hline \multirow[t]{2}{*}{ governance } & $0.004^{* * *}$ & $-0.014 * * *$ & $-0.002^{* * *}$ & $-0.016^{* * *}$ & $-0.002^{* *}$ & $-0.016^{* * *}$ & $-0.002^{* *}$ & $-0.013^{* * *}$ & $-0.002 * *$ & $-0.016^{* * *}$ & $-0.002 * *$ & $-0.015^{* * *}$ \\
\hline & $(0.001)$ & $(0.003)$ & $(0.001)$ & $(0.004)$ & $(0.001)$ & $(0.004)$ & $(0.001)$ & $(0.004)$ & $(0.001)$ & $(0.004)$ & $(0.001)$ & $(0.004)$ \\
\hline \multirow[t]{2}{*}{ regulatory quality } & $0.005^{* * *}$ & -0.003 & $0.005^{* * *}$ & 0.000 & $0.005^{* * *}$ & -0.005 & $0.005^{* * *}$ & -0.005 & $0.005^{* * *}$ & -0.004 & $0.005^{* * *}$ & -0.005 \\
\hline & $(0.001)$ & $(0.003)$ & $(0.001)$ & $(0.003)$ & $(0.001)$ & $(0.003)$ & $(0.001)$ & $(0.003)$ & $(0.001)$ & $(0.003)$ & $(0.001)$ & $(0.003)$ \\
\hline \multirow[t]{2}{*}{ rule of law } & $0.007 * * *$ & -0.001 & $0.004 * * *$ & 0.005 & $0.005^{* * *}$ & 0.001 & $0.004^{* * *}$ & -0.002 & $0.005^{* * *}$ & 0.001 & $0.005^{* * *}$ & -0.001 \\
\hline & $(0.001)$ & $(0.003)$ & $(0.001)$ & $(0.004)$ & $(0.001)$ & $(0.004)$ & $(0.001)$ & $(0.004)$ & $(0.001)$ & $(0.004)$ & $(0.001)$ & $(0.004)$ \\
\hline control of corruption & $0.003^{* * *}$ & $0.014^{* * *}$ & $0.003^{* * *}$ & $0.012^{* * *}$ & $0.003^{* * *}$ & $0.015^{* * *}$ & $0.001^{*}$ & $0.015^{* * *}$ & $0.003^{* * *}$ & $0.017 * * *$ & $0.003^{* * *}$ & $0.016^{* * *}$ \\
\hline & $(0.001)$ & $(0.004)$ & $(0.001)$ & $(0.005)$ & $(0.001)$ & $(0.005)$ & $(0.001)$ & $(0.005)$ & $(0.001)$ & $(0.005)$ & $(0.001)$ & $(0.005)$ \\
\hline Constant & -0.243 & 1.075 & $-1.541 * * *$ & 0.929 & $-0.926 * * *$ & $2.751^{*}$ & $-0.419 *$ & $3.061 * *$ & $-0.959 * * *$ & $2.652^{*}$ & $-0.949 * * *$ & $2.867^{*}$ \\
\hline & $(0.226)$ & (1.195) & $(0.252)$ & (1.434) & $(0.257)$ & $(1.514)$ & $(0.231)$ & $(1.438)$ & $(0.257)$ & $(1.516)$ & $(0.256)$ & (1.514) \\
\hline Firm FE & $\mathrm{N}$ & $\mathrm{N}$ & $\mathrm{N}$ & $\mathrm{N}$ & $\mathrm{N}$ & $\mathrm{N}$ & $\mathrm{N}$ & $\mathrm{N}$ & $\mathrm{N}$ & $\mathrm{N}$ & $\mathrm{N}$ & $\mathrm{N}$ \\
\hline Industry FE & Y & Y & Y & $\mathrm{Y}$ & $\mathrm{Y}$ & $\mathrm{Y}$ & $\mathrm{Y}$ & Y & Y & $\mathrm{Y}$ & $\mathrm{Y}$ & $\mathrm{Y}$ \\
\hline Destination FE & $\mathrm{Y}$ & Y & $\mathrm{Y}$ & $\mathrm{Y}$ & Y & Y & Y & Y & Y & $\mathrm{Y}$ & Y & Y \\
\hline Year FE & Y & $\mathrm{Y}$ & $\mathrm{Y}$ & Y & Y & $\mathrm{Y}$ & $\mathrm{Y}$ & $\mathrm{Y}$ & $\mathrm{Y}$ & $\mathrm{Y}$ & $\mathrm{Y}$ & $\mathrm{Y}$ \\
\hline Observations & 33,803 & 10,681 & 33,803 & 10,681 & 33,803 & 10,681 & 33,803 & 10,681 & 33,803 & 10,681 & 33,803 & 10,681 \\
\hline R-squared & 0.327 & 0.442 & 0.166 & 0.199 & 0.131 & 0.105 & 0.295 & 0.193 & 0.128 & 0.103 & 0.138 & 0.106 \\
\hline
\end{tabular}

Standard errors in parentheses

*** $\mathrm{p}<0.01, * * \mathrm{p}<0.05, * \mathrm{p}<0.1$ 
Table A.3: M\&A Value and RCA (intensive margin)

\begin{tabular}{|c|c|c|c|c|c|c|c|c|c|}
\hline & $\begin{array}{l}(1) \\
\text { Full }\end{array}$ & $\begin{array}{l}\text { (2) } \\
\text { Full }\end{array}$ & $\begin{array}{l}\text { (3) } \\
\text { Full }\end{array}$ & $\begin{array}{l}(4) \\
\text { Full }\end{array}$ & $\begin{array}{c}(5) \\
2001-14\end{array}$ & $\begin{array}{c}(6) \\
2015-18\end{array}$ & $\begin{array}{l}\text { (7) } \\
\text { Full }\end{array}$ & $\begin{array}{c}(8) \\
2001-14\end{array}$ & $\begin{array}{c}(9) \\
2015-18\end{array}$ \\
\hline & \multicolumn{9}{|c|}{ Dep Var: M\&A Value } \\
\hline$R C A^{\text {dest }}$ & $\begin{array}{c}0.191 * * * \\
(0.072)\end{array}$ & $\begin{array}{c}0.193 * * * \\
(0.073)\end{array}$ & $\begin{array}{c}0.351^{* * *} \\
(0.084)\end{array}$ & $\begin{array}{c}0.190 * * \\
(0.084)\end{array}$ & $\begin{array}{c}0.561 * * * \\
(0.096)\end{array}$ & $\begin{array}{c}-0.181^{*} \\
(0.110)\end{array}$ & $\begin{array}{l}-0.013 \\
(0.073)\end{array}$ & $\begin{array}{c}0.370^{* * *} \\
(0.111)\end{array}$ & $\begin{array}{c}-0.245^{* * *} \\
(0.093)\end{array}$ \\
\hline$R C A^{C H}$ & $\begin{array}{c}-1.120^{* * *} \\
(0.366)\end{array}$ & $\begin{array}{c}-1.142^{* * *} \\
(0.367)\end{array}$ & $\begin{array}{c}-0.725 * * * \\
(0.099)\end{array}$ & $\begin{array}{c}-0.806 * * * \\
(0.097)\end{array}$ & $\begin{array}{c}-1.350^{* *} \\
(0.527)\end{array}$ & $\begin{array}{c}3.296 \\
(3.266)\end{array}$ & $\begin{array}{c}-1.050^{* * *} \\
(0.375)\end{array}$ & $\begin{array}{c}-2.840 * * * \\
(0.586)\end{array}$ & $\begin{array}{c}3.294 \\
(2.652)\end{array}$ \\
\hline$R C A^{\text {dest }} \times L A C$ & & $\begin{array}{l}-0.323 \\
(0.342)\end{array}$ & & $\begin{array}{c}3.954 * * * \\
(0.424)\end{array}$ & $\begin{array}{c}-1.468 * * * \\
(0.482)\end{array}$ & $\begin{array}{c}0.201 \\
(0.617)\end{array}$ & & & \\
\hline$R C A^{C H} \times L A C$ & & $\begin{array}{c}1.357 * * * \\
(0.384)\end{array}$ & & $\begin{array}{c}1.875^{* * *} \\
(0.389)\end{array}$ & $\begin{array}{l}-0.009 \\
(0.557)\end{array}$ & $\begin{array}{c}2.453 * * * \\
(0.656)\end{array}$ & & & \\
\hline$R C A^{d e s t} \times R C A^{C H}$ & & & & & & & $\begin{array}{c}-0.357 * * * \\
(0.110)\end{array}$ & $\begin{array}{c}-0.495^{* * *} \\
(0.159)\end{array}$ & $\begin{array}{c}0.019 \\
(0.154)\end{array}$ \\
\hline GDP growth & $\begin{array}{c}0.036 \\
(0.030)\end{array}$ & $\begin{array}{c}0.037 \\
(0.030)\end{array}$ & $\begin{array}{c}0.027 \\
(0.036)\end{array}$ & $\begin{array}{c}0.043 \\
(0.036)\end{array}$ & $\begin{array}{l}-0.024 \\
(0.038)\end{array}$ & $\begin{array}{l}-0.363^{*} \\
(0.217)\end{array}$ & $\begin{array}{c}(0.110) \\
-0.086 * * *\end{array}$ & $\begin{array}{c}(0.159) \\
-0.134^{* * *}\end{array}$ & $\begin{array}{l}(0.154) \\
-0.016\end{array}$ \\
\hline Inflation & $\begin{array}{c}0.110^{* *} \\
(0.044)\end{array}$ & $\begin{array}{c}0.120^{* * *} \\
(0.044)\end{array}$ & $\begin{array}{c}0.163 * * * \\
(0.052)\end{array}$ & $\begin{array}{c}0.200^{* * *} \\
(0.051)\end{array}$ & $\begin{array}{c}0.164 * * * \\
(0.062)\end{array}$ & $\begin{array}{l}-0.100 \\
(0.166)\end{array}$ & $\begin{array}{c}(0.031) \\
0.040\end{array}$ & $\begin{array}{c}(0.040) \\
-0.240^{* * *}\end{array}$ & $\begin{array}{l}(0.182) \\
-0.016\end{array}$ \\
\hline $\operatorname{REER}(-$, depreciation) & $\begin{array}{l}-0.000 \\
(0.006)\end{array}$ & $\begin{array}{l}-0.001 \\
(0.006)\end{array}$ & $\begin{array}{l}-0.012 \\
(0.008)\end{array}$ & $\begin{array}{c}-0.019 * * \\
(0.008)\end{array}$ & $\begin{array}{c}-0.046^{* * *} \\
(0.010)\end{array}$ & $\begin{array}{c}-0.125^{* *} \\
(0.050)\end{array}$ & $\begin{array}{c}(0.043) \\
0.003\end{array}$ & $\begin{array}{c}(0.060) \\
-0.058^{* * *}\end{array}$ & $\begin{array}{l}(0.138) \\
-0.039\end{array}$ \\
\hline $\operatorname{Ln}$ (export) & $\begin{array}{c}0.690^{* *} \\
(0.293)\end{array}$ & $\begin{array}{c}0.738^{* *} \\
(0.293)\end{array}$ & $\begin{array}{c}1.633 * * * \\
(0.345)\end{array}$ & $\begin{array}{c}2.029 * * * \\
(0.339)\end{array}$ & $\begin{array}{c}0.696^{*} \\
(0.407)\end{array}$ & $\begin{array}{c}0.736 \\
(1.287)\end{array}$ & $\begin{array}{c}(0.006) \\
-0.679 * *\end{array}$ & $\begin{array}{c}(0.011) \\
0.138\end{array}$ & $\begin{array}{c}(0.042) \\
0.481\end{array}$ \\
\hline $\operatorname{Ln}$ (import) & $\begin{array}{l}-0.751 \\
(0.527)\end{array}$ & $\begin{array}{l}-0.734 \\
(0.527)\end{array}$ & $\begin{array}{c}0.938 \\
(0.736)\end{array}$ & $\begin{array}{c}0.710 \\
(0.721)\end{array}$ & $\begin{array}{c}2.562^{* * *} \\
(0.807)\end{array}$ & $\begin{array}{l}-0.445 \\
(1.201)\end{array}$ & $\begin{array}{c}(0.308) \\
1.528^{* * *}\end{array}$ & $\begin{array}{c}(0.457) \\
3.190^{* * *}\end{array}$ & $\begin{array}{l}(1.071) \\
-0.604\end{array}$ \\
\hline Accountability & $\begin{array}{c}-0.037 * * \\
(0.018)\end{array}$ & $\begin{array}{c}-0.040^{* *} \\
(0.018)\end{array}$ & $\begin{array}{c}0.088^{* * *} \\
(0.021)\end{array}$ & $\begin{array}{c}0.067 * * * \\
(0.020)\end{array}$ & $\begin{array}{c}0.144^{* * *} \\
(0.027)\end{array}$ & $\begin{array}{l}-0.001 \\
(0.077)\end{array}$ & $\begin{array}{c}(0.518) \\
-0.019\end{array}$ & $\begin{array}{c}(0.871) \\
0.177 * * *\end{array}$ & $\begin{array}{l}(1.006) \\
-0.041\end{array}$ \\
\hline Political stability & $\begin{array}{c}0.048^{* * *} \\
(0.008)\end{array}$ & $\begin{array}{c}0.048^{* * *} \\
(0.008)\end{array}$ & $\begin{array}{c}0.016 \\
(0.010)\end{array}$ & $\begin{array}{c}0.020^{* *} \\
(0.010)\end{array}$ & $\begin{array}{c}0.053^{* * *} \\
(0.012)\end{array}$ & $\begin{array}{l}-0.046^{*} \\
(0.027)\end{array}$ & $\begin{array}{c}(0.018) \\
0.056^{* * *}\end{array}$ & $\begin{array}{c}(0.029) \\
-0.020\end{array}$ & $\begin{array}{c}(0.062) \\
-0.079 * * *\end{array}$ \\
\hline Governance & $\begin{array}{c}-0.106^{* * *} \\
(0.025)\end{array}$ & $\begin{array}{c}-0.113^{* * *} \\
(0.025)\end{array}$ & $\begin{array}{c}-0.065^{* *} \\
(0.031)\end{array}$ & $\begin{array}{c}-0.095^{* * *} \\
(0.031)\end{array}$ & $\begin{array}{c}-0.126^{* * *} \\
(0.035)\end{array}$ & $\begin{array}{l}-0.136 \\
(0.093)\end{array}$ & $\begin{array}{c}(0.008) \\
-0.168^{* * *}\end{array}$ & $\begin{array}{c}(0.012) \\
-0.122^{* * *}\end{array}$ & $\begin{array}{c}(0.022) \\
-0.032\end{array}$ \\
\hline Regulatory quality & $\begin{array}{c}-0.096^{* * *} \\
(0.021)\end{array}$ & $\begin{array}{c}-0.103^{* * *} \\
(0.021)\end{array}$ & $\begin{array}{c}-0.099 * * * \\
(0.026)\end{array}$ & $\begin{array}{c}-0.100 * * * \\
(0.025)\end{array}$ & $\begin{array}{c}-0.267 * * * \\
(0.032)\end{array}$ & $\begin{array}{l}0.161^{* *} \\
(0.069)\end{array}$ & $\begin{array}{c}(0.025) \\
-0.042^{* *}\end{array}$ & $\begin{array}{c}(0.037) \\
-0.221 * * *\end{array}$ & $\begin{array}{l}(0.076) \\
0.133^{* *}\end{array}$ \\
\hline Rule of law & $\begin{array}{c}0.181 * * * \\
(0.029)\end{array}$ & $\begin{array}{c}0.195^{* * *} \\
(0.029)\end{array}$ & $\begin{array}{c}0.121 * * * \\
(0.033)\end{array}$ & $\begin{array}{c}0.213^{* * *} \\
(0.034)\end{array}$ & $\begin{array}{c}0.185^{* * *} \\
(0.046)\end{array}$ & $\begin{array}{c}0.180^{* *} \\
(0.079)\end{array}$ & $\begin{array}{c}(0.020) \\
0.119 * * *\end{array}$ & $\begin{array}{c}(0.034) \\
0.286^{* * *}\end{array}$ & $\begin{array}{c}(0.057) \\
0.229 * * *\end{array}$ \\
\hline Control of corruption & $\begin{array}{c}0.001 \\
(0.020)\end{array}$ & $\begin{array}{c}0.005 \\
(0.021)\end{array}$ & $\begin{array}{c}0.081 * * * \\
(0.025)\end{array}$ & $\begin{array}{c}0.021 \\
(0.025)\end{array}$ & $\begin{array}{c}0.107 * * * \\
(0.031)\end{array}$ & $\begin{array}{c}0.150 \\
(0.100)\end{array}$ & $\begin{array}{c}(0.031) \\
0.045^{* *}\end{array}$ & $\begin{array}{c}(0.048) \\
0.004\end{array}$ & $\begin{array}{c}(0.067) \\
0.068\end{array}$ \\
\hline Firm FE & $\mathrm{N}$ & $\mathrm{N}$ & $\mathrm{Y}$ & Y & $\mathrm{N}$ & $\mathrm{N}$ & $\mathrm{N}$ & $\mathrm{N}$ & $\mathrm{N}$ \\
\hline Industry FE & $\mathrm{Y}$ & $\mathrm{Y}$ & $\mathrm{Y}$ & $\mathrm{Y}$ & $\mathrm{Y}$ & $\mathrm{Y}$ & $\mathrm{Y}$ & $\mathrm{Y}$ & $\mathrm{Y}$ \\
\hline Destination FE & $\mathrm{Y}$ & $\mathrm{Y}$ & $\mathrm{Y}$ & $\mathrm{Y}$ & $\mathrm{Y}$ & $\mathrm{Y}$ & $\mathrm{Y}$ & $\mathrm{Y}$ & $\mathrm{Y}$ \\
\hline Year FE & Y & Y & $\mathrm{Y}$ & $\mathrm{Y}$ & Y & $\mathrm{Y}$ & Y & $\mathrm{Y}$ & Y \\
\hline Obs & 4,254 & 4,254 & 2,846 & 2,846 & 3,202 & 1,286 & 4,226 & 2,986 & 1,754 \\
\hline R-square & 0.469 & 0.470 & 0.862 & 0.869 & 0.573 & 0.269 & 0.346 & 0.517 & 0.380 \\
\hline
\end{tabular}

Standard errors in parentheses *** $\mathrm{p}<0.01, * * \mathrm{p}<0.05, * \mathrm{p}<0.1$ 
Table A.4: Pooled Regressions of Advanced Economies

\begin{tabular}{|c|c|c|c|c|}
\hline & $\begin{array}{l}(1) \\
\text { Extensive } \\
\text { Margin }\end{array}$ & $\begin{array}{c}(2) \\
\text { Extensive } \\
\text { Margin }\end{array}$ & $\begin{array}{c}(3) \\
\text { Intensive } \\
\text { Margin }\end{array}$ & $\begin{array}{l}\text { (4) } \\
\text { Intensive } \\
\text { Margin }\end{array}$ \\
\hline & \multicolumn{4}{|c|}{ Dep Var: M\&A Dummy } \\
\hline$R C A^{\text {dest }}$ & $\begin{array}{c}-0.011 * * * \\
(0.001)\end{array}$ & $\begin{array}{c}-0.011 * * * \\
(0.001)\end{array}$ & $\begin{array}{c}-0.057 * * * \\
(0.012)\end{array}$ & $\begin{array}{c}-0.083^{* * *} \\
(0.014)\end{array}$ \\
\hline$R C A^{\text {origin }}$ & $\begin{array}{c}0.110^{* * *} \\
(0.008)\end{array}$ & $\begin{array}{c}0.099 * * * \\
(0.008)\end{array}$ & $\begin{array}{c}0.432^{* * *} \\
(0.105)\end{array}$ & $\begin{array}{c}0.419 * * * \\
(0.105)\end{array}$ \\
\hline$R C A^{\text {dest }} \times L A C$ & & $\begin{array}{c}0.017^{* * *} \\
(0.003)\end{array}$ & & $\begin{array}{c}0.132^{* * *} \\
(0.030)\end{array}$ \\
\hline$R C A^{\text {origin }} \times L A C$ & & $\begin{array}{c}0.241 * * * \\
(0.009)\end{array}$ & & $\begin{array}{l}-0.090 \\
(0.111)\end{array}$ \\
\hline GDP growth & $\begin{array}{c}0.004 * * * \\
(0.000)\end{array}$ & $\begin{array}{c}0.004 * * * \\
(0.000)\end{array}$ & $\begin{array}{c}0.130 * * * \\
(0.004)\end{array}$ & $\begin{array}{c}0.131 * * * \\
(0.004)\end{array}$ \\
\hline Inflation & $\begin{array}{l}-0.001 \\
(0.001)\end{array}$ & $\begin{array}{l}-0.001 \\
(0.001)\end{array}$ & $\begin{array}{c}0.076^{* * *} \\
(0.009)\end{array}$ & $\begin{array}{c}0.075^{* * *} \\
(0.009)\end{array}$ \\
\hline REER (-, depreciation) & $\begin{array}{c}-0.000^{* * *} \\
(0.000)\end{array}$ & $\begin{array}{c}-0.000^{* * *} \\
(0.000)\end{array}$ & $\begin{array}{l}-0.001 \\
(0.001)\end{array}$ & $\begin{array}{l}-0.000 \\
(0.001)\end{array}$ \\
\hline $\mathrm{Ln}$ (export) & $\begin{array}{c}0.004 \\
(0.003)\end{array}$ & $\begin{array}{c}0.002 \\
(0.003)\end{array}$ & $\begin{array}{c}-0.595^{* * *} \\
(0.042)\end{array}$ & $\begin{array}{c}-0.591 * * * \\
(0.042)\end{array}$ \\
\hline Ln(import) & $\begin{array}{c}-0.025^{* * *} \\
(0.004)\end{array}$ & $\begin{array}{c}-0.029 * * * \\
(0.004)\end{array}$ & $\begin{array}{c}1.061 * * * \\
(0.054)\end{array}$ & $\begin{array}{c}1.048^{* * *} \\
(0.054)\end{array}$ \\
\hline Accountability & $\begin{array}{c}0.001^{* * *} \\
(0.000)\end{array}$ & $\begin{array}{c}0.001^{* * *} \\
(0.000)\end{array}$ & $\begin{array}{c}-0.047 * * * \\
(0.004)\end{array}$ & $\begin{array}{c}-0.045^{* * *} \\
(0.004)\end{array}$ \\
\hline Political stability & $\begin{array}{c}-0.001 * * * \\
(0.000)\end{array}$ & $\begin{array}{c}-0.000 * * * \\
(0.000)\end{array}$ & $\begin{array}{c}0.003^{*} \\
(0.001)\end{array}$ & $\begin{array}{l}0.002^{*} \\
(0.001)\end{array}$ \\
\hline Governance & $\begin{array}{c}0.001 * * \\
(0.000)\end{array}$ & $\begin{array}{l}0.001 * \\
(0.000)\end{array}$ & $\begin{array}{c}-0.012^{* * *} \\
(0.004)\end{array}$ & $\begin{array}{c}-0.013 * * * \\
(0.004)\end{array}$ \\
\hline Regulatory quality & $\begin{array}{c}0.002^{* * *} \\
(0.000)\end{array}$ & $\begin{array}{c}0.002^{* * *} \\
(0.000)\end{array}$ & $\begin{array}{c}0.030 * * * \\
(0.004)\end{array}$ & $\begin{array}{c}0.029 * * * \\
(0.004)\end{array}$ \\
\hline Rule of law & $\begin{array}{c}0.003^{* * *} \\
(0.000)\end{array}$ & $\begin{array}{c}0.004 * * * \\
(0.000)\end{array}$ & $\begin{array}{c}0.074 * * * \\
(0.004)\end{array}$ & $\begin{array}{c}0.073^{* * *} \\
(0.004)\end{array}$ \\
\hline Control of corruption & $\begin{array}{c}0.000^{* *} \\
(0.000)\end{array}$ & $\begin{array}{c}0.001 * * \\
(0.000)\end{array}$ & $\begin{array}{c}-0.020 * * * \\
(0.003)\end{array}$ & $\begin{array}{c}-0.018^{* * *} \\
(0.003)\end{array}$ \\
\hline Origin FE & Y & $\mathrm{Y}$ & $\mathrm{Y}$ & Y \\
\hline Industry FE & Y & $\mathrm{Y}$ & $\mathrm{Y}$ & $\mathrm{Y}$ \\
\hline Destination FE & $\mathrm{Y}$ & Y & $\mathrm{Y}$ & $\mathrm{Y}$ \\
\hline Year FE & Y & Y & Y & Y \\
\hline Obs & 637,023 & 637,023 & 53,050 & 53,050 \\
\hline R-square & 0.024 & 0.025 & 0.731 & 0.731 \\
\hline
\end{tabular}




\begin{tabular}{|c|c|c|c|c|c|c|}
\hline & (1) & (2) & & (4) & (5) & (6) \\
\hline & \multicolumn{6}{|c|}{ Dep Var: M\&A dummy } \\
\hline$R C A^{d e s t}$ & $\begin{array}{c}0.007 * * * \\
(0.003)\end{array}$ & $\begin{array}{c}0.009 * * * \\
(0.003)\end{array}$ & $\begin{array}{c}0.028^{* * *} \\
(0.004)\end{array}$ & $\begin{array}{c}0.030 * * * \\
(0.004)\end{array}$ & $\begin{array}{c}0.017 * * * \\
(0.005)\end{array}$ & $\begin{array}{c}0.021^{* * *} \\
(0.005)\end{array}$ \\
\hline $\mathrm{Ln}(\mathrm{FAI}$ in the past 3 years) & $\begin{array}{c}0.009 * * * \\
(0.001)\end{array}$ & $\begin{array}{c}0.008^{* * *} \\
(0.001)\end{array}$ & $\begin{array}{c}0.010^{* * *} \\
(0.002)\end{array}$ & $\begin{array}{c}0.009 * * * \\
(0.002)\end{array}$ & & \\
\hline $\begin{array}{l}\text { Sectoral PPI in the past } 3 \\
\text { years }\end{array}$ & & & & & $\begin{array}{c}0.003 * * * \\
(0.001)\end{array}$ & $\begin{array}{c}0.002^{* * *} \\
(0.001)\end{array}$ \\
\hline$R C A^{\text {dest }} \times L A C$ & & $\begin{array}{l}-0.021 * \\
(0.011)\end{array}$ & & $\begin{array}{l}-0.044^{*} \\
(0.023)\end{array}$ & & $\begin{array}{c}-0.046^{* *} \\
(0.020)\end{array}$ \\
\hline $\begin{array}{l}\mathrm{Ln}(\mathrm{FAI} \text { in the past } 3 \\
\text { years)*LAC }\end{array}$ & & $\begin{array}{c}0.018^{* * *} \\
(0.007)\end{array}$ & & $\begin{array}{l}0.016^{* *} \\
(0.008)\end{array}$ & & \\
\hline $\begin{array}{l}\text { Sectoral PPI in the past } 3 \\
\text { years*LAC }\end{array}$ & & & & & & $\begin{array}{l}0.006^{*} \\
(0.003)\end{array}$ \\
\hline GDP growth & $\begin{array}{c}0.008^{* * *} \\
(0.001)\end{array}$ & $\begin{array}{c}0.008^{* * *} \\
(0.001)\end{array}$ & $\begin{array}{l}-0.001 \\
(0.001)\end{array}$ & $\begin{array}{l}-0.001 \\
(0.001)\end{array}$ & $\begin{array}{c}0.009 * * * \\
(0.002)\end{array}$ & $\begin{array}{c}0.008^{* * *} \\
(0.002)\end{array}$ \\
\hline inflation & $\begin{array}{c}-0.017 * * * \\
(0.002)\end{array}$ & $\begin{array}{c}-0.017 * * * \\
(0.002)\end{array}$ & $\begin{array}{c}-0.020^{* * *} \\
(0.002)\end{array}$ & $\begin{array}{c}-0.020^{* * *} \\
(0.002)\end{array}$ & $\begin{array}{l}-0.005^{*} \\
(0.003)\end{array}$ & $\begin{array}{l}-0.005 \\
(0.003)\end{array}$ \\
\hline REER & $\begin{array}{c}0.001 * * * \\
(0.000)\end{array}$ & $\begin{array}{c}0.001 * * * \\
(0.000)\end{array}$ & $\begin{array}{c}0.001 * * * \\
(0.000)\end{array}$ & $\begin{array}{c}0.001 * * * \\
(0.000)\end{array}$ & $\begin{array}{c}0.000 \\
(0.000)\end{array}$ & $\begin{array}{l}0.000 \\
(0.000)\end{array}$ \\
\hline $\ln ($ export to China) & $\begin{array}{c}0.072^{* * *} \\
(0.010)\end{array}$ & $\begin{array}{c}0.070 * * * \\
(0.010)\end{array}$ & $\begin{array}{c}0.067 * * * \\
(0.010)\end{array}$ & $\begin{array}{c}0.065^{* * *} \\
(0.010)\end{array}$ & $\begin{array}{c}0.103 * * * \\
(0.022)\end{array}$ & $\begin{array}{c}0.103 * * * \\
(0.022)\end{array}$ \\
\hline $\ln$ (import from China) & $\begin{array}{c}-0.025^{*} \\
(0.015)\end{array}$ & $\begin{array}{c}-0.032^{* *} \\
(0.015)\end{array}$ & $\begin{array}{c}-0.080^{* * *} \\
(0.014)\end{array}$ & $\begin{array}{c}-0.085^{* * *} \\
(0.014)\end{array}$ & $\begin{array}{c}-0.127 * * * \\
(0.029)\end{array}$ & $\begin{array}{c}-0.124 * * * \\
(0.029)\end{array}$ \\
\hline accountability & $\begin{array}{c}0.002^{* *} \\
(0.001)\end{array}$ & $\begin{array}{c}0.002 * * * \\
(0.001)\end{array}$ & $\begin{array}{c}-0.003^{* * *} \\
(0.001)\end{array}$ & $\begin{array}{c}-0.002^{* * *} \\
(0.001)\end{array}$ & $\begin{array}{c}0.012^{* * *} \\
(0.001)\end{array}$ & $\begin{array}{c}0.012^{* * *} \\
(0.001)\end{array}$ \\
\hline political stability & $\begin{array}{c}0.001 * * \\
(0.000)\end{array}$ & $\begin{array}{c}0.001 * * \\
(0.000)\end{array}$ & $\begin{array}{c}-0.001 * * * \\
(0.000)\end{array}$ & $\begin{array}{c}-0.001 * * * \\
(0.000)\end{array}$ & $\begin{array}{c}-0.005^{* * *} \\
(0.001)\end{array}$ & $\begin{array}{c}-0.005^{* * *} \\
(0.001)\end{array}$ \\
\hline governance & $\begin{array}{c}-0.002^{* *} \\
(0.001)\end{array}$ & $\begin{array}{c}-0.002^{* *} \\
(0.001)\end{array}$ & $\begin{array}{c}0.002 * * \\
(0.001)\end{array}$ & $\begin{array}{c}0.002^{* *} \\
(0.001)\end{array}$ & $\begin{array}{l}-0.003^{*} \\
(0.002)\end{array}$ & $\begin{array}{l}-0.003^{*} \\
(0.002)\end{array}$ \\
\hline regulatory quality & $\begin{array}{c}0.004 * * * \\
(0.001)\end{array}$ & $\begin{array}{c}0.004 * * * \\
(0.001)\end{array}$ & $\begin{array}{c}-0.003 * * * \\
(0.001)\end{array}$ & $\begin{array}{c}-0.003^{* * *} \\
(0.001)\end{array}$ & $\begin{array}{c}0.000 \\
(0.002)\end{array}$ & $\begin{array}{c}0.000 \\
(0.002)\end{array}$ \\
\hline rule of law & $\begin{array}{l}-0.001 \\
(0.001)\end{array}$ & $\begin{array}{l}-0.002 \\
(0.001)\end{array}$ & $\begin{array}{c}0.004 * * * \\
(0.001)\end{array}$ & $\begin{array}{c}0.003 * * * \\
(0.001)\end{array}$ & $\begin{array}{c}0.005^{* * *} \\
(0.002)\end{array}$ & $\begin{array}{c}0.005^{* * *} \\
(0.002)\end{array}$ \\
\hline control of corruption & $\begin{array}{c}-0.004 * * * \\
(0.001)\end{array}$ & $\begin{array}{c}-0.003^{* * *} \\
(0.001)\end{array}$ & $\begin{array}{l}-0.001 \\
(0.001)\end{array}$ & $\begin{array}{l}-0.000 \\
(0.001)\end{array}$ & $\begin{array}{c}-0.007 * * * \\
(0.001)\end{array}$ & $\begin{array}{c}-0.007 * * * \\
(0.001)\end{array}$ \\
\hline Firm FE & $\mathrm{N}$ & $\mathrm{N}$ & $\mathrm{Y}$ & Y & $\mathrm{N}$ & $\mathrm{N}$ \\
\hline Industry FE & Y & Y & $\mathrm{N}$ & $\mathrm{N}$ & Y & Y \\
\hline Destination FE & Y & Y & $\mathrm{Y}$ & $\mathrm{Y}$ & Y & Y \\
\hline Year FE & $\mathrm{Y}$ & $\mathrm{Y}$ & Y & Y & $\mathrm{Y}$ & $\mathrm{Y}$ \\
\hline Obs & 39,547 & 39,547 & 40,484 & 40,484 & 11,609 & 11,609 \\
\hline R-square & 0.043 & 0.043 & 0.204 & 0.204 & 0.135 & 0.136 \\
\hline
\end{tabular}

Standard errors in parentheses

$* * * \mathrm{p}<0.01, * * \mathrm{p}<0.05, * \mathrm{p}<0.1$ 
Table A.6: M\&A of Advanced Economies, by sector and destination

\begin{tabular}{|c|c|c|c|c|c|c|c|}
\hline & EAP & ECA & LAC & MENA & NA & SAR & SSA \\
\hline \multicolumn{8}{|c|}{ Average deal value (US\$ million, 2001-18) } \\
\hline Basic Materials \& Energy & 132 & 395 & 143 & 358 & 371 & 152 & 322 \\
\hline Consumer & 147 & 315 & 189 & 196 & 427 & 139 & 368 \\
\hline Financials & 286 & 299 & 298 & 144 & 485 & 187 & 194 \\
\hline Health and Technology & 114 & 248 & 95 & 178 & 318 & 108 & 128 \\
\hline Industrials & 122 & 230 & 128 & 166 & 215 & 86 & 73 \\
\hline Telecommunication Services & 101 & 471 & 583 & 272 & 383 & 227 & 451 \\
\hline Utilities & 296 & 772 & 277 & 207 & 507 & 90 & 108 \\
\hline \multicolumn{8}{|c|}{ Number of deals (2001-18) } \\
\hline Basic Materials \& Energy & 1966 & 8394 & 1604 & 227 & 4247 & 297 & 489 \\
\hline Consumer & 2853 & 18142 & 1179 & 341 & 4765 & 597 & 277 \\
\hline Financials & 1488 & 10457 & 577 & 173 & 2559 & 319 & 147 \\
\hline Health and Technology & 1925 & 11968 & 579 & 474 & 6420 & 572 & 110 \\
\hline Industrials & 2346 & 16070 & 981 & 263 & 4957 & 575 & 224 \\
\hline Telecommunication Services & 454 & 2738 & 175 & 89 & 1014 & 103 & 75 \\
\hline Utilities & 117 & 1731 & 199 & 26 & 433 & 55 & 23 \\
\hline
\end{tabular}

